A Life-Cycle Cost Data Base

For Assessing

Acid Deposition

Damage to

Common Building

Materials
Stephen F. Weber

Barbara C. Lippiatt Matthew Wiener

October 1985

NBSIR 85-3253

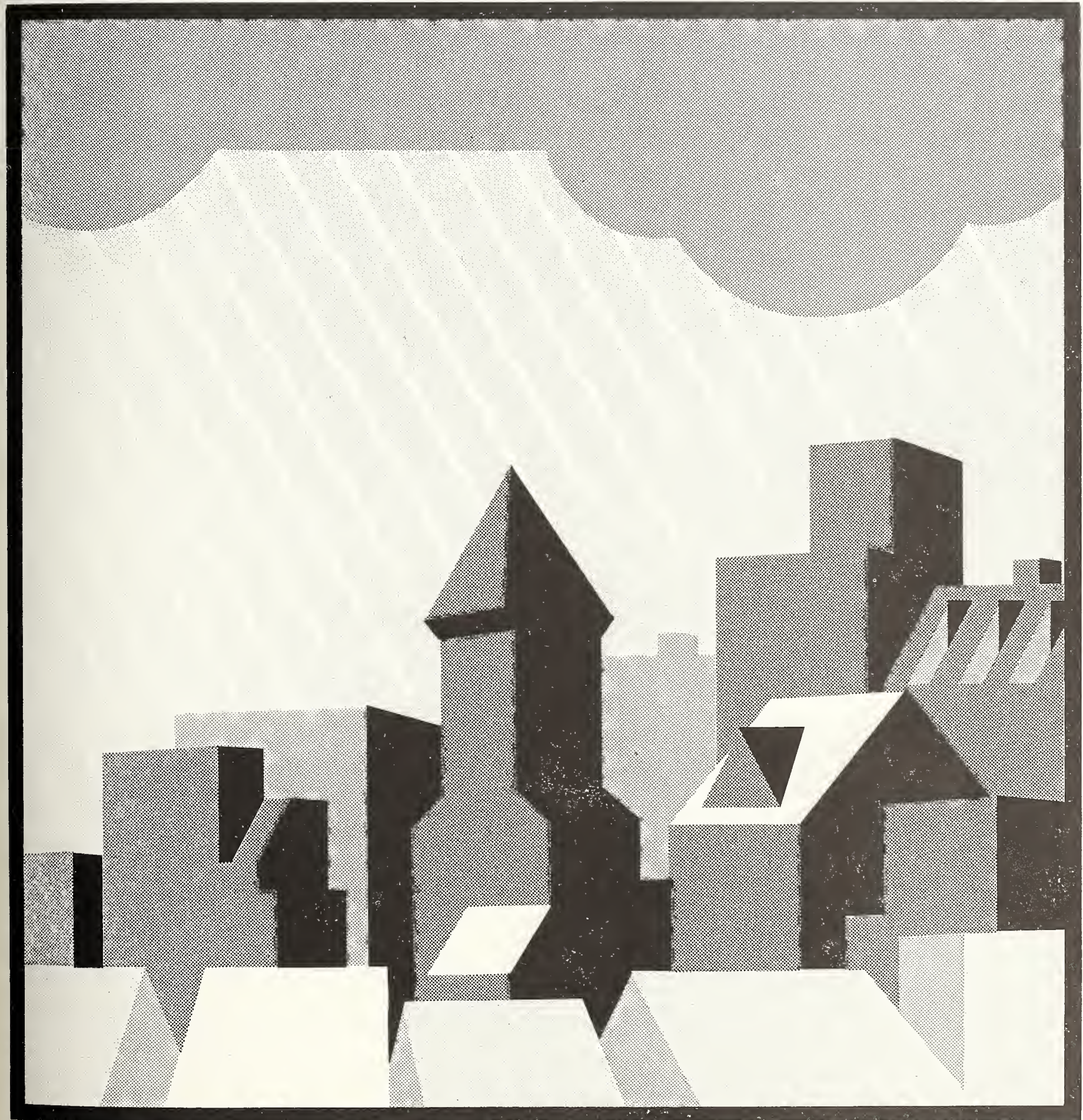

U.S. DEPARTMENT OF
COMMERCE

National Bureau of Standards

Center for Applied

Mathematics

Applied Economics Group

Gaithersburg, MD 20899

Sponsored by:

U.S. ENVIRONMENTAL

PROTECTION AGENCY

National Acid Precipitation

Assessment Program

Materials Effects Task Group

(Group G) 



\section{A LIFE-CYCLE COST DATA BASE FOR ASSESSING ACID DEPOSITION DAMAGE TO COMMON BUILDING MATERIALS}

Stephen F. Weber Barbara C. Lippiatt Matthew Wiener

U.S. DEPARTMENT OF COMMERCE

National Bureau of Standards

Center for Applied Mathematics

Gaithersburg, MD 20899

October 1985

Sponsored by:

U.S. Environmental Protection Agency

Washington, DC 20460

As Part of:

National Acid Precipitation Assessment Program

Materials Effects Task Group [Group G]

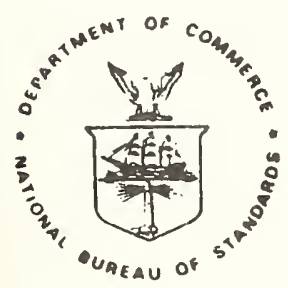

U.S. DEPARTMENT OF COMMERCE, Malcolm Baldrige, Secretary NATIONAL BUREAU OF STANDARDS, Ernest Ambler, Director 


\section{ABSTRACT}

This report presents and documents cost data for the most economically significant building materials suspected of being damaged by acid deposition. The data are presented in the form of cost estimates for relevant maintenance, repair, and replacement (MR\&R) activities, and are organized both by building component and by building material. The building components covered in this report include walls, roofs, fences, rain gutters, and downspouts. The materials covered include paint, limestone, marble, galvanized steel, copper, and masonry mortar. The documentation describes the data sources and presents detailed technical specifications for each of the 360 cost estimates contained in the data base. Summary statistics are presented for groups of MR\&R activities, and the techniques of analysis of variance and regression analysis are used to address the problem of variation in the cost estimates within the same activity group. The report also explains and illustrates how the cost data can be used to estimate the economic cost of acid deposition damage to common building components and materials. 


\section{ACKNOWLEDGMENTS}

The authors are grateful to Richard LIvingston, John Spence, and Tom Lareau of the U.S. Environmental Protection Agency, to Susan Sherwood of the U.S. Department of the Interfor, to Frederick Lipfert of the Brookhaven National Laboratory, and to Ke1th Eberhardt, Harold Marshal1, Jonathan Martin, Mary Natrella, Stephen Petersen, and Joan Rosenblatt of the National Bureau of Standards for the many useful comments and suggestions they provided on earlier drafts of this report. Appreclation is also owed to Alice Booher, Amy House, and Laurene Linsenmayer of the National Bureau of Standards for their assistance in manuscript preparation. 
In view of the currently accepted practice of the building industry in the United States, some common U.S. units of measurement have been used in this report. In recognition of the position of the United States as a signatory to the General Conference of Weights and Measures, which gave official status to the metric SI system of units in 1960, appropriate conversion factors have been provided in the table below. The reader interested in making further use of the coherent system of SI units is referred to:

U.S. Department of Commerce, National Bureau of Standards.

The International System of Units (SI), NBS Special Publication 330, 1977 Edition. (Washington, DC: U.S. Government Printing Office, 1977.)

Metric Conversion Factors

Length:

Area:

Mass:
1 inch $(i n)=25.4$ milimeters (mm)

1 foot $(f t)=0.3048$ meter $(m)$

$1 \mathrm{ft}^{2}=0.092903 \mathrm{~m}^{2}$

1 ounce $(o z)=28.3495 \mathrm{gram}(g)$ 


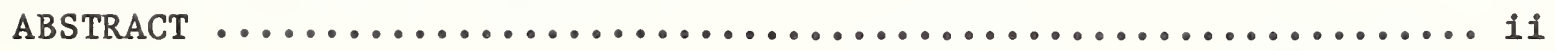

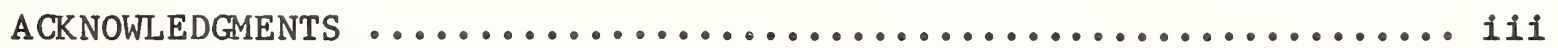

SI CONVERSION $\ldots \ldots \ldots \ldots \ldots \ldots \ldots \ldots \ldots \ldots \ldots \ldots \ldots \ldots$ iv

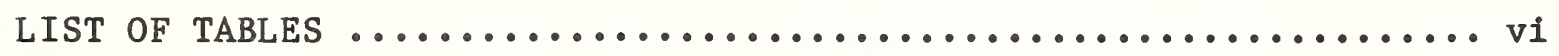

1. INTRODUCTION

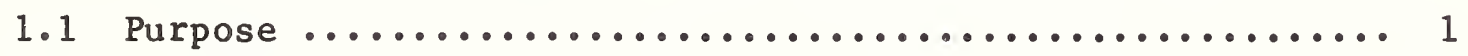

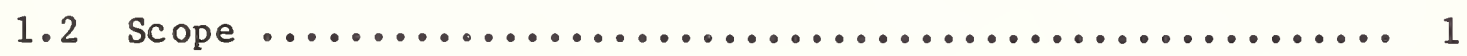

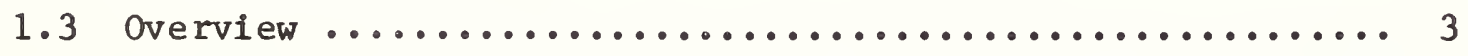

2. COST DATA COLLECTION

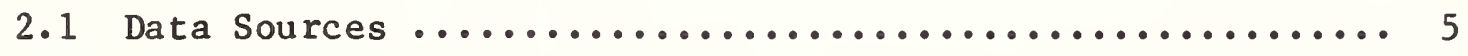

2.2 Data Collection Method ....................... 8

3. COST DATA PRESENTATION

3.1 Summary Statistics for the General MR\&R Categories ...... 10

3.2 Methods of Addressing Variation within MR\&R Categories ... 12

4. APPLICATION OF THE COST DATA

4.1 Relationship to Other Data ........................ 19

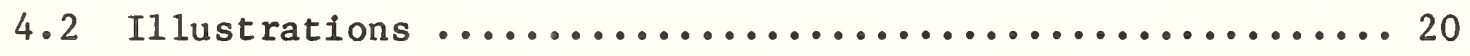

5. SUMMARY, CONCLUSIONS, AND RESEARCH NEEDS

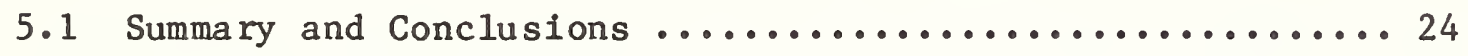

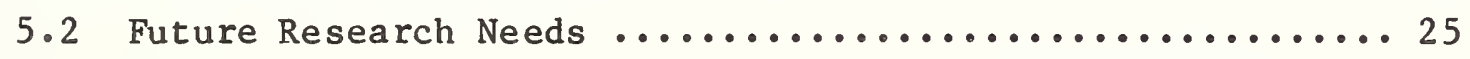

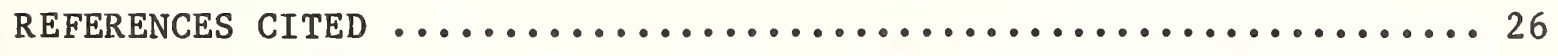

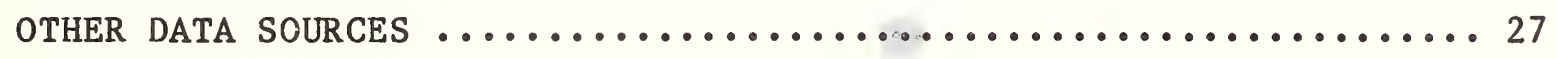

APPENDIX A: BUILDING INVENTORY WORKSHEET FOR PILOT STUDY $\ldots \ldots \ldots 28$

APPENDIX B: LIFE-CYCLE COST DATA BASE ..................... 33

APPENDIX C: ADJUSTING FOR LOCAL VARIATIONS IN COSTS ........ 59

APPENDIX D: OTHER ADJUSTMENTS $\ldots \ldots \ldots \ldots \ldots \ldots \ldots \ldots \ldots \ldots \ldots \ldots \ldots \ldots \ldots \ldots \ldots$ 
1.1 Building Components and Materials Included in the Life-Cycle Page

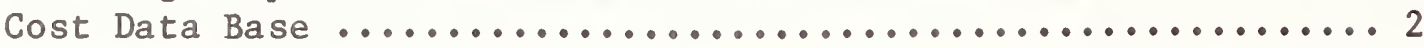

1.2 Building Components and Maintenance, Repair, and Replacement Activity Groups Used to Organize Cost Data ............... 3

2.1 Characteristics of Data Sources Used to Develop the Data

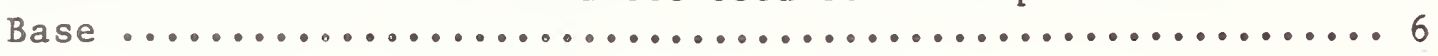

2.2 Relative Labor and Marerials Costs, by Construction Division .. 9

3.1 Summary Statistics of Cost Data (1984 \$) by General MR\&R

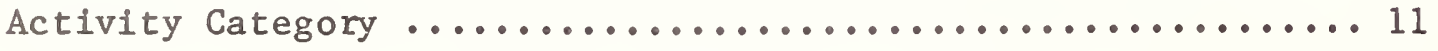

3.2 Results of Analysis of Variance to Test the Nominal Significance of Breaking General MR\&R Categories into Smaller Groups of More Homogeneous Data .................... 13

3.3 Summary Statistics of Cost Data by Building Component and

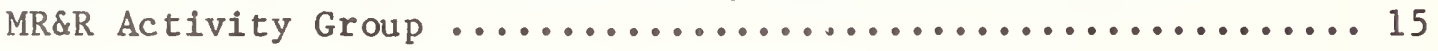

3.4 Results of Regression Analysis for Unpainted Walls, Gutters

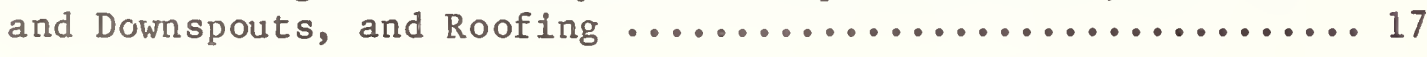

4.1 Application Costs of Coating Systems (1981 $\left.\$ / \mathrm{ft}^{2}\right) \ldots \ldots \ldots \ldots 21$

4.2 Expected Service Lives (Years) of Coating Systems in Various

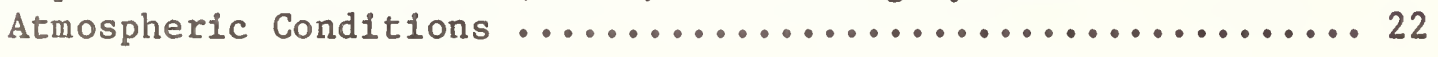

4.3 Discounted Annualized Cost (1981 \$/10,000 SF/year) for Coating Systems in Various Atmospheric Conditions

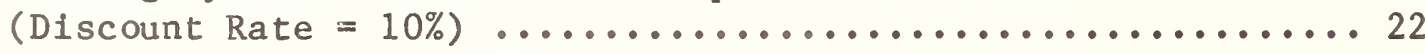

B.1 Identification Codes Used for Data Sources in the Data

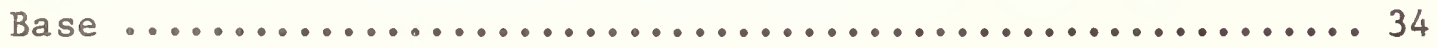

\section{DATABASE TABLES}

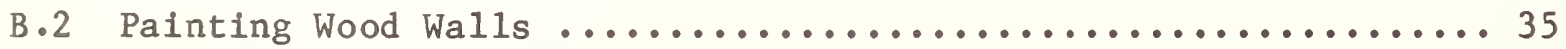

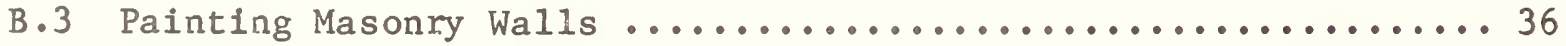

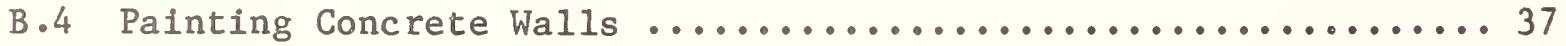

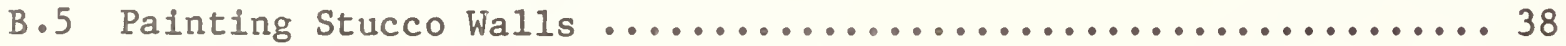

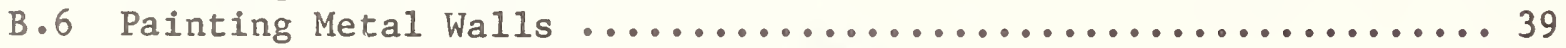


B.7 Galvanized Steel Siding ......................... 40

B.8 Indiana Limestone Walls .......................... 41

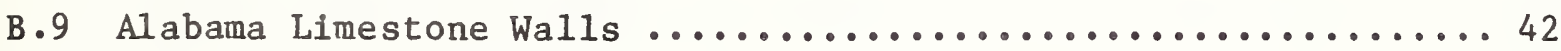

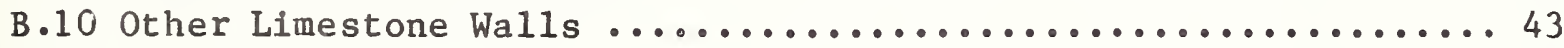

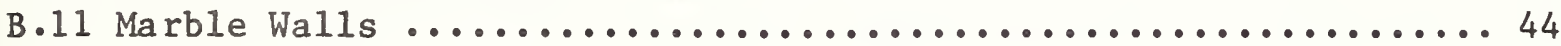

B.12 Repointing Brick Walls ........................... 45

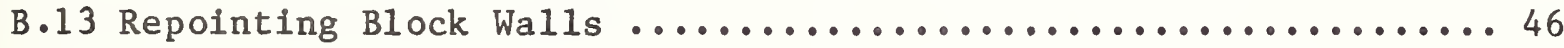

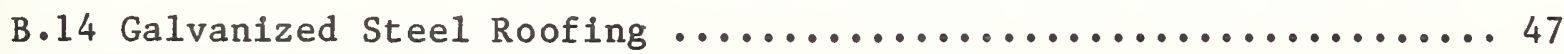

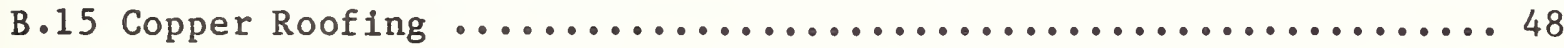

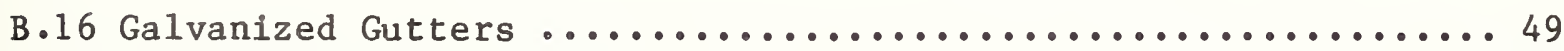

B.17 Copper Gutters ................................ 50

B.18 Galvanized Downspouts (Residential) .................. 51

B.19 Galvanized Downspouts (Commercial) .................... 52

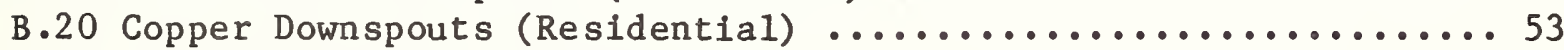

B.21 Copper Downspouts (Commercial) ...................... 54

B.22 Galvanized Steel Chain Link Fencing ................... 55

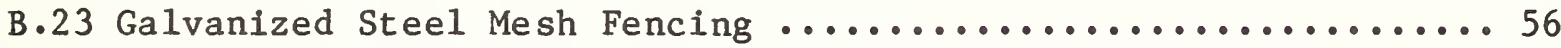

B.24 Residential Galvanized Steel Gates ................... 57

B.25 Commercial Galvanized Steel Gates ..................... 58

C.1 Construction Divisions for Building Components and MR\&R

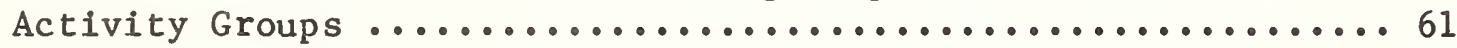

C.2 Geographic Adjustment Factors Used to Convert U.S. Average Cost Estimates to Their Local Equivalent Values for 156 Cities, by Type of Construction Activity ............... 62

D.1 MR\&R Activity Cost Using Non-Union Labor, as a Percent of MR\&R Activity Cost Using Union Labor ...................... 69

D.2 Percent to Add to MR\&R Activity Cost with New Construction Overhead and Profit to Obtain Equivalent Cost with Replacement Construction Overhead and Profit .................. 70

D.3 MR\&R Activity Cost Using Non-Union Labor with Replacement Construction Overhead and Profit, as a Percent of MR\&R Activity Cost Using Union Labor with New Construction Overhead and

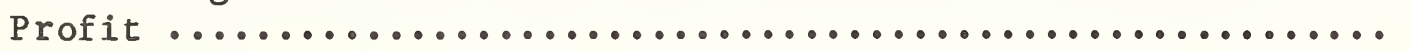

D.4 Percent to Add to Replacement MR\&R Activity Cost to Account for Special Job Requirements, by Building Component and Material and by Job Requirement [Minimum \% - Maximum \%] ......73 


\subsection{Purpose}

One of the major objectives of the National Acid Precipitation Assessment Program (NAPAP) is to quantify the dollar cost of acid deposition damage to common building materials. This report provides a key element in the link between the physical damage functions being derived by the Materials Effects Task Group and the dollar estimates of damage to building materials to be derived by the Assessment and Policy Task Group. The purposes of this report are: (1) to present detailed data on the maintenance, repair, and replacement costs for common bullding components and materials that are susceptible to acid deposition damage; and (2) to describe how these cost data should be combined with estimates of the effects of acid deposition on component/material durability to derive a dollar damage estimate per unit of building component for each material. The cost data presented here have been obtained from several national data bases maintained and regularly updated by private firms. This project did not include the derivation of new data. The objective was rather to identify the existing data sources and to evaluate their usefulness for estimating the costs of acid damage to building materials.

\subsection{Scope}

The particular building components and materials included in this report were selected on the basis of the original Building Inventory Worksheet for Pilot Study that was developed as part of this research project and used in the Materials Inventory Survey Pilot Study conducted in New Haven, Connecticut. (The Worksheet is included in appendix A of this report.) The components and materials given in the revised Building Inventory Worksheet used for those sites surveyed after the New Haven Pilot Study are substantially the same as those in the original Worksheet. The revisions consist mainly of reorganization, simplification, and the addition of an explicit system for computer coding of the inventory data.

The 1ist of building components and materials for which cost data are included in the data base is presented in table 1.1. Five basic components of buildings are included: walls, roofs, rain gutters, downspouts, and fences. For each of these components, several building materials are specified. These particular component/material combinations were selected because they are expected to contribute significantly to the magnitude of the economic damage resulting from acid precipitation. This is expected for several reasons. First, these components are commonly found on the exterior of buildings, and are therefore exposed to acid precipitation. Second, the materials specified here are susceptible to damage from acid precipitation, according to damage functions being derived in other research efforts within the Materials Effects Task Group of NAPAP. Third, the costs associated with the maintenance, repair, and replacement activities related to these components and materials are significant in most building management budgets. 
Table 1.1 Bullding Components and Materials Included in the Lifa-Cycle Cost Data Base

Bullding Component

Walls

Roofs

Gutters

Downspouts

Fences
Building Material

Paint

Galvanized steel

Limestone

Marble

Masonry mortar

Galvanized steel

Copper

Galvanized steel

Copper

Galvanized steel

Copper

Galvanized steel

The 12 component/material combinations given in table 1.1 can be used to define general categorles of construction activities that involve elther the maintenance, repalr, or replacement of the bullding component. For example, the wall/paint combination suggests the maintenance activity of painting exterior walls. Similarly, the combination of wall/masonry mortar suggests the repair activity of repointing the mortar joints of masonry walls. The remaining combinations suggest other activities such as replacement of gutters and downspouts. Cost estimates for a large number of very specific maintenance, repair, and replacement (MR\&R) activities that fall within each of these general categories were collected from published construction cost manuals, as described in section 2. Because there was considerable variation among the cost estlinates within some of the 12 general categories, several methods of dividing the categories into smaller groups of more homogeneous data were tested. For example, the cost estimates for painting walls were divided into flve groups according to substrate, and the estimates for replacing limestone walls were divided into three groups according to origin of the stone. This process, described in section 3, resulted in the 24 MR\&R activity groups listed in table 1.2. Except for painting walls and repointing brick and block walls, the MR\&R activities refer to the replacement of the component 1isted. These MR\&R activity groups are used to organize the presentation and analysis of the cost data throughout the renainder of this report. Because the report includes (In appendix B) the complete details of each data point, the reader is able to reorganize the cost data in whatever way best serves a particular research objective. 
Table 1.2 Bu1lding Components and Maintenance, Repair, and Replacement Activity Groups Used to Organize Cost Data

Building Component

Walls

Roofs

Gutters

Downspouts

Fences

\section{MR\&R Activity Group}

\author{
Painting Wood \\ Painting Masonry \\ Painting Concrete \\ Painting Stucco \\ Painting Metal
}

Galvanized Steel

Indiana Limestone

Alabama Limestone

other Limestone

Marble

Repointing Brick

Repointing Block

Galvanized Steel

Copper

Galvanized Steel

Copper

Galvanized Residential

Galvanized Commercial

Copper Residential

Copper Commercial

Galvanized Link Fencing

Galvanized Mesh Fencing

Galvanized Residential Gates

Galvanized Commercial Gates

\subsection{Overview}

The next section of this report describes how the cost data were collected for the $24 \mathrm{MR} \&$ activities listed in table 1.2. The published data sources are discussed and the data collection method is explained. 
Section 3 of the report presents summary statistics (sample size, minlmum, maximum, median, mean, and coefflclent of varlation) for each of the 24 MRAR activities. This section also summarizes the results of the analy $81 \mathrm{~s}$ of the groupings used and the results of the regression analysis conducted to explain some of the variation within the MR\&R activity groups.

Section 4 explains how the cost data presented here are related to the data being produced by other research efforts within NAPAP. Several numerical examples are used to illustrate how the cost data are to be combined with the physical damage functions, the data on the effects of damage on the frequency of MR\&R activities, and the materials inventory data to derive estimates of the dollar cost of the damage to common building materials resulting from acid precipitation. Section 5 summarizes the research results and identifies future research needs.

The report concludes with a list of references, a list of other sources of life-cycle cost data, and four appendices. Appendix A contains the Building Inventory Worksheet developed under this project. Appendix B contains the detalls of each of the 360 data points in the life-cycle cost data base. For each data point, appendix B presents the cost estinate of the MR\&R activity, the published data source and page number from which the estinate was derived, and all of the technical specifications given by the published data source. Appendix $C$ presents a table of geographic adjustment factors and describes a method to apply those factors to convert the U.S. average cost estimates of appendix B to their local equivalent values for 156 cities. Appendix D presents methods for adjusting the cost data to take into account the base period, labor type (union or non-union), project type (new or repair and replacement construction), and economies of scale. 


\section{COST DATA COLLECTION}

\subsection{Data Sources}

A literature search was conducted for reliable life-cycle cost data on the building components and materials listed in table 1.1. Eighteen published sources of relevant information were identified. Three criteria were employed to select the most useful of these 18 sources. The sources had to be (1) standard cost estimating reference sources used throughout the construction industry, (2) updated regularly, and (3) basically consistent with one another. The six published construction cost manuals which met these criteria are listed in table 2.1. The remaining 10 information sources are given in the Other Data Sources listed at the end of the report.

The Berger, Dodge, and Means manuals develop their cost data in the same manner. 1 The cost estimate of any given MR\&R activity is constructed from data on the five factors affecting total cost: (1) materials cost, (2) wage rates, (3) crew definition, (4) crew output rate, and (5) overhead and profit rates. Materials costs are updated annually through contacts with product manufacturers and manufacturers' sales representatives. Union wage rates are collected annually from union halls; Berger and Dodge use averages which vary by trade for 20 major U.S. cities, and MEANS REP \& REM uses averages which vary by trade for the 30 largest U.S. cities. Crew definitions and output rates are developed for the Dodge and Means manuals based on the professional experience and construction industry contacts of staff estimators and engineers. Berger uses averages of crew definitions and output rates for contractors in 20 cities. Crew definitions and output rates remain the same from year to year unless staff research or reader comments reveal changes in contruction practice. Overhead and profit are derived from a combination of regularly updated and standard data bases for the Berger, Dodge, and Means manuals. Because insurance and tax rates (except social security taxes) vary among states and among construction firms, averages are used. Other overhead expenses usually depend on the size of the firm; averages for these expenses as well as for subcontractors' profit margins are used in the cost manuals.

The Boeckh manual was used for fence and gate cost data only. Boeckh collects total installed costs for fences from contractors and fence suppliers, and then reports the average total cost. 2

Table 2.1 presents the major characteristics of the six cost manuals. These characteristics are important in determining cost compatibility from source to source. Cost compatibility among sources is necessary to permit the costs found in one manual to be combined with those found in another manual to create a consistent sample of cost estimates.

${ }^{1}$ Details on how the published sources develop the cost data were obtained directly from the manuals themselves and from the following telephone conversations: Seymour Berger, BERGER, 7/3/85, Percival E. Pereira, DODGE SYSTEMS and DODGE PRICING, 7/8/85, and Melville J. Mossman, MEANS REP \& REM and MEANS RES/LT COM, 7/2/85.

${ }^{2}$ Telephone conversation with Terry Ness, BOECKH, 7/8/85. 
Table 2.1 Characteristics of Data Sources Used to Develop the Data Base

Data Source

Characteristic

\begin{tabular}{lccccc}
\hline BERGER & BOECKHa & DODGE & DODGE & MEANS & MEANS \\
& & SYSTEMS & PRICING & REP \& REM & RES/LT COM
\end{tabular}

Base Period Mid-84 Jan-82 Early-84 Mid-84 Jan-84 $\quad$ Jan-84

Subcontractor

O\&P Included

Yes Yes

Yes Yes

Yes

Yes

Yes

Genera1

Contractor

O\&P Included

No

No

Yes

No

No

No

Project

Type

New \& Replace

New

New

Replace

New

Building

Project

Replace

$2,515^{b}$

250

$<400$

Size (\$1000)

End-use

Res/

Res

Com/Ind

Res/ Com

Res/

Com/Ind

Res/

Sector ${ }^{C}$

Union Union

Union Union

Union

Light Com

Labor Type

SOURCES :

BERGER: Building Cost File, Inc. The 1984 Berger Building \& Design Cost File. (Vol. 1: General Construction Trades--Unit Prices).

Hicksville, NY: 1984.

BOECKH: E. H. Boeckh Co. Underwriter's Valuation Manual. Milwaukee, WI:

Ame rican Appraisal Associates, Inc., 1984.

DODGE SYSTEMS: McGraw-H111 Cost Information Systems. 1984 Dodge Construction System Costs. (1984 Construction Cost Information, Vol. 1). Princeton, NJ: 1983.

DODGE PRICING: McGraw-H111 Cost Information Systems. 1984 Dodge Manual for Building Construction Pricing and Scheduling. 19th Annual

Edition (1984 Construction Cost Information, Vol. 2). Princeton, NJ: 1983.

MEANS REP \& REM: Robert Snow Means Company, Inc. Repair and Remodeling Cost Data: Commercial/Residential 1984. 5th Annual Edition. Kingston, MA: 1984.

MEANS RES/LT COM: Robert Snow Means Company, Inc. Residential/Light Commercial Cost Data 1984. 3rd Annual Edition. Kingston, MA:

NOTES : 1984.

a Characteristics listed for BOECKH apply to its residential fence and gate cost data only.

b Average of commercial building costs taken from DODGE SYSTEMS, p. 26.

$c$ Res = Residential, Com = Commercial, Ind = Industrial 
As table 2.1 indicates, five of the six cost manuals use a base year of 1984 for their cost estimates. The cost estimates from the Boeckh manual have a base year of 1982. These costs were converted to a base period of January 1984 using time-location multipliers that Boeckh reports for this purpose. 1 (Since no national averages were given for the Boeckh time multipliers, the multipliers for Massachusetts were used under the assumption that this state is representative of the geographic area of NAPAP interest.) Consequently, al1 the cost estimates presented in appendix B have a base year of 1984 , although the base period (i.e, month) within 1984 varies among the sources. With appropriate conversion factors, the cost estimates could be converted to any common base period desired. Because more cost estimates in this data base are taken from the Means manuals, the factors needed to convert the Berger and Dodge estimates to the Means base period of January 1984 are given and illustrated in appendix $D$.

The cost estimates reported in the manuals are national average construction costs and may need to be adjusted to account for local cost variations. Because more of the cost estimates presented in this report are derived from the two Means manuals, the Means City Cost Index systein is most appropriate for deriving local construction cost estimates fron the U.S. average cost estimate. Another reason for using the Means system is that it provides separate indexes for 16 distinct construction divisions. These separate division indexes take into account the variation among divisions in the relative importance of materials versus labor costs. The following construction divisions are most relevant for the MR\&R activities discussed in this report: Masonry, Metals, Moisture Protection, and Painting. Appendix C presents a table of geographic indexes for these construction divisions and illustrates how to apply the factors to the cost estimates of appendix $B$.

It can be seen from table 2.1 that costs from all but one source include overhead and profit of subcontractors only. Costs collected from DODGE SYSTEMS include general contractor overhead and profit as well as subcontractor overhead and profit. Based on an inquiry made of Dodge, 2 ten percent was subtracted from the cost estimates collected from DODGE SYSTEMS in order to approximate costs including subcontractor overhead and profit only.

The project type information given in table 2.1 indicates that some of the manuals focus on construction activities associated with new projects (New) while other manuals address activities associated with repair and replacement projects (Replace). A construction activity associated with a repair and replacement project tends to cost more than the same activity associated with a new construction project for two reasons. First, the subcontractor's overhead and profit rates are higher for a replacement project because a subcontractor working on the smaller replacement project tends to have a lower overall volume of business. Secondly, there are a number of costly tasks that are often required with repair and replacement work, such as dust and noise protection of non-construction areas. Appendix D provides and illustrates the use of percentage amounts that can be applied to the new construction cost estimates of appendix $B$ in order to account for these special repair and replacement cost items. These figures were derived using relative labor and

$1_{\text {BOECKH, pp. HTLM1-HTLM2O. }}$

${ }^{2}$ Telephone conversation with Percival E. Pereira, Chief Editor, DODGE SYSTEMS, $10 / 26 / 84$. 
materials costs for the four relevant construction divisions. Table 2.2 presents these labor and materials percentages for the four construction divisions and for a weighted average of all 16 construction divisions.

The six data sources used for this report give cost estimates for subcontracted items of work that are part of a general contractor's project for an entire building or complex of buildings. Subcontracted items of work tend to cost less per unit in large building projects because of economies of scale. Means has developed a method of adjusting costs to take this into account. (The method is presented in appendix D.) Table 2.1 gives the approximate cost of the typical building projects used by each data source, reflecting the sizes of the projects.1

As indicated by the "end-use sector" listings given in table 2.1, the construction cost data reported by all of the manuals apply to the types of buildings addressed by the Materials Inventory Survey being conducted by the Materials Effects Task Group. Thus, these data are conpatible with the scope of this project.

Unionized labor is the basis of the wage rates reported in all the cost manuals except MEANS RES/LT COM, as can be seen in the bottom row of table 2.1. All the union labor based cost estimates presented in appendix B could be converted to a non-union basis. Appendix D describes and illustrates a conversion method.

\subsection{Data Collection Method}

A worksheet form was developed for each general MR\&R category in order to facilitate collection of relevant data from the manuals. Worksheets for all MR\&R categories specified total cost, units in which total cost was reported, cost manual from which the cost data were obtained, with page number, and job specification. The job specification entry was for listing any other details given on the activity. For example, some of the completed worksheets on galvanized steel fences included the length of fence sections in the job specification. Details that were expected to have a significant impact on the cost estimate were listed separately. For example, the worksheet for galvanized steel siding included an entry for gauge. Such details varied from one activity to another.

Once the worksheet forms were developed, the six cost manuals were searched for cost estimates for the MR\&R activities of interest, and a worksheet was filled out for each estimate found. Three hundred and sixty cost estimates were collected.

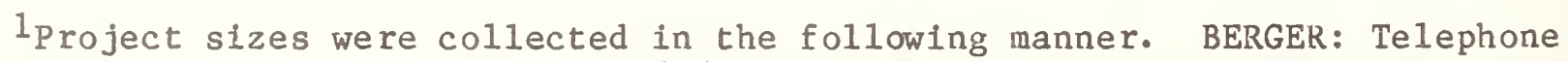
conversation with Seymour Berger, 7/3/85; BOECKH: Average across the 21 residential building types valued on pp. R32-R73; DODGE SYSTEMS: Average across the 47 average bullding costs, p. 26; DODGE PRICING: Average across the 41 average commercial bullding costs, DODGE SYSTEMS, p. 26; MEANS REP \& REM: p. 11; MEANS RES/LT COM: p. 11. 
Table 2.2 Relative Labor and Materials Costs, by Construction Division

\begin{tabular}{lcc}
\hline $\begin{array}{l}\text { Construction } \\
\text { Division }\end{array}$ & $\begin{array}{c}\text { Labor Cost } \\
\text { Total Cost }(\%)\end{array}$ & $\begin{array}{c}\text { Materials Cost: } \\
\text { Total Cost }(\%)\end{array}$ \\
\hline Masonry & 77.3 & 22.7 \\
Metals & 34.7 & 65.3 \\
Molsture Protection & 31.5 & 68.5 \\
Painting & 78.0 & 22.0 \\
Weighted Average & 54.0 & 46.0 \\
\hline
\end{tabular}

Source: R. S. Means Co., Inc., Building Construction Cost Data 1984

(Kingston, MA: 1984), pp. 323-331. 


\section{COST DATA PRESENTATION}

The cost data collection effort resulted in a data base of 360 MR\&R activity cost estimates. Each estimate is derived directly from one of the six published data sources described in section 2. This section first presents descriptive statistics to summarize the cost data for the general MR\&R activity categories. Then the sources of cost variation within the general categories are discussed and examined with the statistical techniques of analysis of variance and regression analysis. Each of the 360 cost estimates with its technical specifications as obtained from the published data source is presented in appendix $B$.

\subsection{Summary Statistics for the General MR\&R Categories}

Table 3.1 reports the summary statistics for 14 general MR\&R activity categories. These categories are derived from the 12 component/material combinations given in table 1.1 of section 1 by dividing masonry mortar into the two categories of brick mortar and block mortar and by adding gates as a category distinct from fences. The masonry category must be divided because the data sources use different units of measurement for brick and block: cost estinates for repointing brick mortar are given in dollars per square foot of wall, while those for repointing block mortar are given in dollars per lineal foot of mortar. Gates are listed separately from fences because the data indicate that their costs depend on different factors. Column 1 of the table lists the building component for each activity category and Column 2 describes each activity by giving the material used. Column 3 gives the sample size, that is, the number of individual cost estimates that were used to derive the summary statistics for that activity category. Column 4 gives the physical units of measurement (square feet (SF) or lineal feet (LF)) in which the individual cost estimates and the summary statistics are stated. Columns 5 through 8 present the maximum, minimum, median, and arithmetic mean, respectively, of the cost estimates for each activity category. These four values are given in 1984 dollars per physical unit of measurement. It is interesting to note that the mean and median values are quite close to each other for almost all of the activity categories. This result means that the distributions of the cost estimates within the categories are quite symmetric.

Column 9 of table 3.1 gives the coefficent of variation for each of the categories. This statistic expresses the sample standard deviation as a percent of the sample mean. Because it is stated as a percent it can be compared across categories. For the categories given in table 3.1, galvanized gates exhibit the greatest variation in cost (relative to the mean) with 80 percent, while copper downspouts show the smallest relative variation with only 19 percent. 


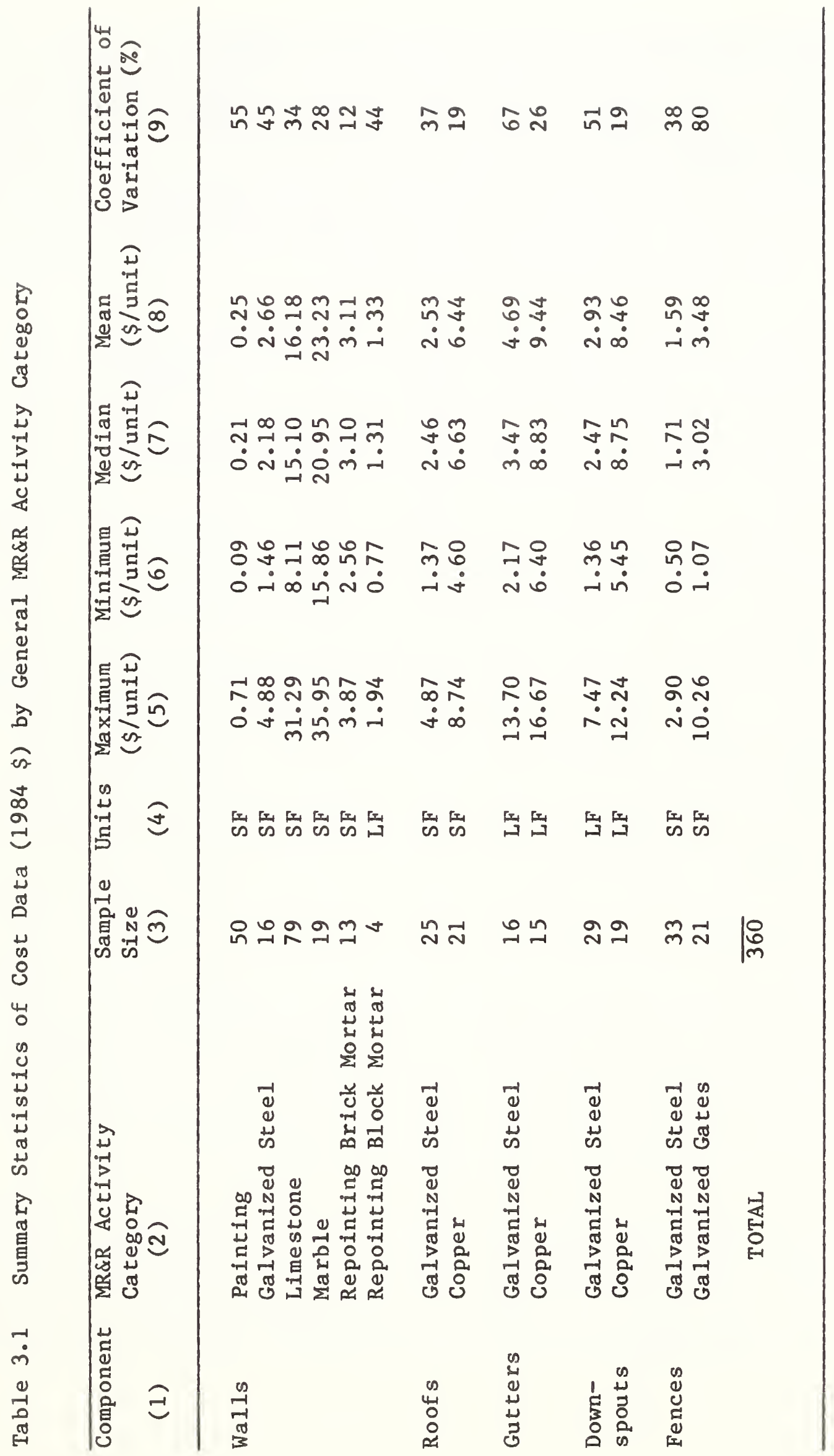




\subsection{Methods of Addressing Variation within MR\&R Categories}

As column 9 of table 3.1 indicates, the cost estimates in many of the general MR\&R activity categories have considerable variation. This variation has two major causes. The first cause relates to the differences inherent in the published cost data sources as explained in section 2. These differences concern such factors as the size of the project (economies of scale), the type of project (new versus replacement), and the labor type employed (union versus non-union). Methods of addressing these sources of variation are discussed in appendix D.

The second cause of variation in the cost estimates concerns the differences in the detailed specifications of the MR\&R activity, even within the same published data source. The more detailed the specifications of an activity, the more likely are independent cost estinates of that activity to lead to the same result. Consequently, one method of reducing the variation in the estimates is to provide more technical specification in defining an activity. This has the effect of distributing the 360 cost estimates in the data base into smaller groups of more hoinogeneous data than the 14 general MR\&R activity categories. Carried to its limit, this method could theoretically lead to 360 separate activity groups, each having only one cost estinate. A more moderate implementation of the method was used on the data base for two reasons. First, the level of detail of the technical specifications required by 360 distinct activity groups is far greater than, and inconsistent with, what could be observed in the Materials Inventory Survey data. This is because 1 imited resources permitted observation of the bulldings only from the street. Secondly, not all of the technical specifications significantly affect cost. Thus, the selection of the appropriate technical specifications was based on whether they could be observed in the inventory data and whether they significantly affect cost. For example, substrate material meets both of these criteria and was used to group data on the cost of painting walls. Similarly, the type of building-commercial or residential--was used to group data on the cost of down spouts.

For eight of the 14 general MR\&R activity categories, it was possible to identify an economically significant technical specification that was reported for every estimate in the category and was expected to be observable in the results of the Materials Inventory Survey. The effect of using these eight specifications to divide the general categories into smaller groups was evaluated with the statistical technique called analysis of variance. The results of this evaluation are summarized in table 3.2 .

Column 4 of table 3.2 gives the number of groups that resulted from the application of the eight technical specifications to the eight corresponding general MR\&R activity categories. These additional specifications resulted in a total of 26 MR\&R activity groups, including those six general categories (indicated by the number 1 in column 4) which were not divided. For each of the eight categories divided into groups, column 5 reports the F-statistic, 
Table 3.2 Results of Analysis of Variance to Test the Nominal Significance of Break1ng General MR\&R Categorles Into Smaller Groups of More Homogeneous Data

\begin{tabular}{|c|c|c|c|c|c|}
\hline $\begin{array}{l}\text { Component } \\
\text { (1) }\end{array}$ & $\begin{array}{c}\text { General MR\&R } \\
\text { Activity Category } \\
\text { (2) }\end{array}$ & $\begin{array}{l}\text { Sample } \\
\text { S1ze } \\
(3)\end{array}$ & $\begin{array}{l}\text { Number of } \\
\text { Groups } \\
\text { (4) }\end{array}$ & $\begin{array}{c}\text { F-Statistic } \\
\text { (5) }\end{array}$ & $\begin{array}{c}\text { Nominal } \\
\text { Significance } \\
\text { Leve1 (\%) } \\
(6)\end{array}$ \\
\hline Walls & $\begin{array}{l}\text { Painting } \\
\text { Galvanized Steel } \\
\text { Limestone } \\
\text { Marble } \\
\text { Repointing Brick } \\
\text { Repointing Block }\end{array}$ & $\begin{array}{r}50 \\
16 \\
79 \\
19 \\
13 \\
4\end{array}$ & $\begin{array}{l}5 \\
1 \\
3 \\
1 \\
1 \\
1\end{array}$ & $\begin{array}{c}3.19 \\
\text { NA } \\
27.19 \\
\text { NA } \\
\text { NA } \\
\text { NA }\end{array}$ & $\begin{array}{l}2.2 \\
\text { NA } \\
0.0 \\
\text { NA } \\
\text { NA } \\
\text { NA }\end{array}$ \\
\hline Roofs & $\begin{array}{l}\text { Galvanized Steel } \\
\text { Copper }\end{array}$ & $\begin{array}{l}25 \\
21\end{array}$ & $\begin{array}{l}1 \\
1\end{array}$ & $\begin{array}{l}\text { NA } \\
\text { NA }\end{array}$ & $\begin{array}{l}\text { NA } \\
\text { NA }\end{array}$ \\
\hline Gutters & $\begin{array}{l}\text { Galvanized Steel } \\
\text { Copper }\end{array}$ & $\begin{array}{l}16 \\
15\end{array}$ & $\begin{array}{l}2 \\
2\end{array}$ & $\begin{array}{l}0.01 \\
2.94\end{array}$ & $\begin{array}{r}92.1 \\
9.0\end{array}$ \\
\hline Downspouts & $\begin{array}{l}\text { Galvanized Stee1 } \\
\text { Copper }\end{array}$ & $\begin{array}{l}29 \\
19\end{array}$ & $\begin{array}{l}2 \\
2\end{array}$ & $\begin{array}{l}7.68 \\
8.07\end{array}$ & $\begin{array}{l}1.0 \\
1.1\end{array}$ \\
\hline Fences & $\begin{array}{l}\text { Fencing } \\
\text { Gates }\end{array}$ & $\begin{array}{l}33 \\
21\end{array}$ & $\begin{array}{l}2 \\
2\end{array}$ & $\begin{array}{l}63.25 \\
21.32\end{array}$ & $\begin{array}{l}0.0 \\
0.0\end{array}$ \\
\hline TOTAL & & $\overline{360}$ & $\overline{26}$ & & \\
\hline
\end{tabular}

NA (Not Applicable) indicates that analysis of variance was not conducted on that general MR\&R category because no natural groups were apparent in the specifications given in the published data sources. 
which is the standard test of the significance of the new grouping. Column 6 presents the nominal significance level implied by the F-statistic for the sample sizes of the category and of the groups within each category. The nominal significance level indicates how appropriate it is to use the technical specification to create the distinct groups for the data set included in the general MR\&R activity category. The word "nominal" means that the data sets analyzed here do not constitute random samples drawn from an identifiable population. Thus, the analytical results are used to describe the data themselves but not to make statistical inferences about a population. Using a required nominal significance level of 5 percent leads to the rejection of the distinction between commercial and residential construction for both galvanized steel gutters and copper gutters. This results in the 24 MR\&R activity groups presented in table 3.3. The same summary statistics given for the 14 general MR\&R categories in table 3.1 are presented for al1 24 MR\&R activity groups in table 3.3. These 24 MR\&R activity groups form the basis for the organization of the detailed presentation of the cost data in appendix $B$.

Technical specifications were used above to reduce the variation in the cost estimates within a category by breaking up the category into smaller groups of more homogeneous data. If a technical specification is a continuous variable (such as thickness) rather than a categorical variable (such as type of substrate), then it can be used to explain directly the cost variation within groups (or categories). This approach to addressing the problem of variation relies on the statistical technique called regression analysis. The cost data for the 24 MR\&R activity groups were studied to find technical specifications that could serve as continuous variables in a regression equation explaining cost. Reasonable variables were found for 11 of the MR\&R activity groups. The analyses were performed using OMNITAB, a statistical analysis program developed at the National Bureau of Standards. 1

The best method of conducting regression analysis on these (non-random) data would be to weight each data point by a factor to reflect the proportion of the population it represents. Because the scope of this project did not permit the development of such weighting factors, the regression analysis was conducted on the unweighted data to discover whether the explanatory variables do influence cost for these data sets. The MR\&R activity groups for which regression analysis was performed fall into three major categories: Unpainted Wal1s, Gutters and Downspouts, and Roofing.

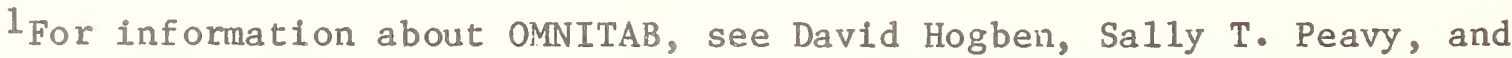
Ruth N. Varner, OMNITAB II User's Reference Manual, NBS Technical Note 552, (Washingt on, DC: U.S. Government Printing Office, 1971). 
UNPAINTED WALLS: The cost data for replacing unpainted walls is stated in dollars per square foot, regardless of the thickness of the limestone or marble panels or the gauge of the galvanized steel. Thickness and gauge are thus the logical candidates to be the explanatory variables in the regression analyses for these MR\&R activity groups. Columns 5 and 6 of table 3.4 give the estimated coefficients of the regression equation. The slope coefficient in column 6 indicates how much and in which direction (increase or decrease) the cost per square foot of the wall changes for every added inch of thickness in the limestone or marble (or for every gauge unit of galvanized steel). For example, an additional inch of thickness is estimated to mean an extra cost of $\$ 2.40$ for Alabama Limestone. The signs of the slope coefficients for Indiana Limestone, Alabama Limestone, and Marble walls are all positive, as expected. The regression for all 30 of the data points for Other Limestone walls yields an unexpected negative slope estimate of -0.94 . Such a negative sign implies that thicker walls are less costly to replace than thinner ones. When the same data are divided according to data source (MRR versus DP), the proper sign is obtained for the 18 DODGE PRICING (DP) data points, while the sign remains negative for the 12 MEANS REP \& REM (MRR) data points.- The unexpected negative sign for the Other Limestone data suggests that cost is influenced by some other variable not included in the regression. The negative value of -0.27 obtained for the slope coefficient for the galvanized steel data is expected since gauge varies inversely with thickness.

Column 8 of table 3.4 reports the R-squared values in percent for each of the regressions. This statistic is interpreted as the percentage of the total variation in the response variable (cost) that is explained by the independent variable (thickness or gauge). The remaining variation in cost is due to other factors that could not be included in the regression. For the Indiana Limestone data set, less than 1 percent of the variation in cost can be explained by thickness. The R-squared values for the other Unpainted Wall regressions indicate that cost is at least partially explained by thickness and gauge.

GUTTERS AND DOWNSPOUTS: The cost per lineal foot of gutters and downspouts is expected to vary as a function of the material required to form the cross section of each component. Since no specifications are given for material thickness, the perimeter of the cross section is a reasonable proxy for this material requirement. For circular downspouts the perimeter of the cross section is equivalent to the circumference of a circle and is computed as the diameter tines $\pi(3.1416)$; for rectangular downspouts the perimeter is computed as the sum of the four sides. The cross-sectional perineter of gutters, which are open along the top, must be computed differently. For semi-circular gutters the perimeter is one half of the circumference of a circle and is computed as one half the diameter times $\pi$; for box-shaped gutters the perimeter is the width plus twice the height of the sides. As table 3.4 indicates, the signs of the estimated slope coefficients are all positive as expected, meaning that an increase in perimeter is more costly. For all but galvanized downspouts the $\mathrm{R}$-squared values indicate that the perimeter explains over 75 percent of the variation in cost. 


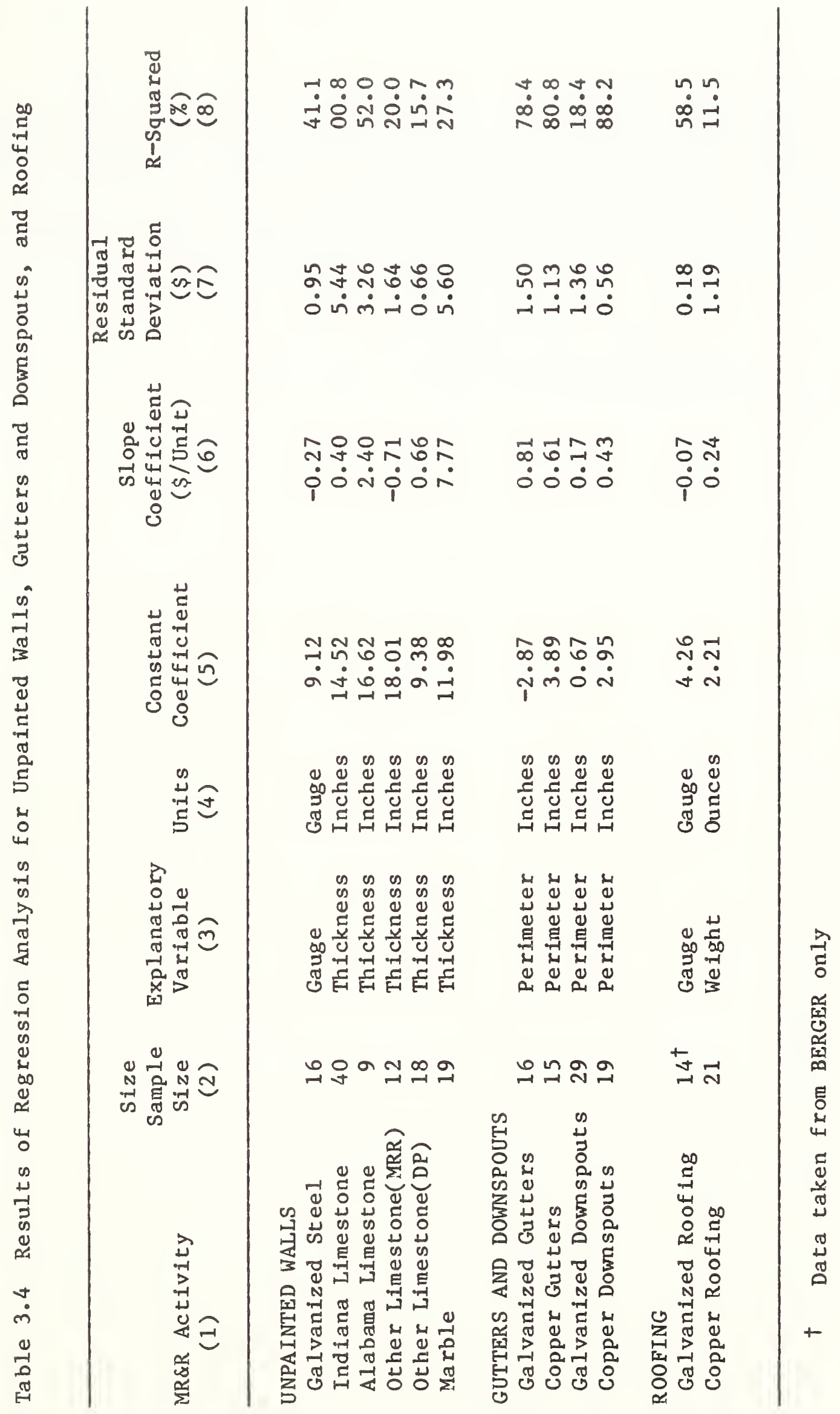


ROOFING: The cost per square foot of roofing is expected to vary as a function of gauge (for galvanized steel) or weight in ounces (for copper). When all 25 data points on steel roofing were included in the regression, the resulting positive slope Indicated that cost rises with the gauge of the steel. Since gauge varies inversely with material thickness, this result suggests that a variable not included in the regression is influencing cost. When data from the single largest data source (BERGER, w1th 14 data points) were analyzed separately, a more neaningful negative slope of -0.07 resulted, with a rather large $R$-squared value of 58.5 percent. For copper roofing the positive slope of 0.24 makes sense because cost per square foot is likely to vary directly with the weight of the copper. The R-squared value for copper roofing is only 11.5 percent. 
This section explains how the cost data can be combined with other data to achieve the primary goal of the Materials Effects Task Group, namely the estimation of the dollar cost of acid deposition damage to buildings. The first subsection discusses the relationship of the life-cycle cost data base presented in this report to the data being developed through other research efforts. The second subsection illustrates with numerical examples how the cost data can be combined with other data to develop dollar estimates of acid deposition damage to buildings.

\subsection{Relationship to Other Data}

The cost data presented in this report need to be combined with three other types of data to derive dollar damage estimates: physical damage functions, critical damage value data, and building materials inventory data. The physical damage functions are expected to relate the amount of damage, as mass or thickness loss per unit time, to the concentration of acid in the environment. For example, in the case of a galvanized coating over steel, the physical damage function might be expressed as the number of microns of thickness expected to be lost per year as a function of the number of micrograms per cubic meter of a particular acidic component in the envi ronment.

Critical damage value data will specify the amount of damage which will cause MR\&R activities to be undertaken. For example, a galvanized coating over steel might need to be replaced once it has lost some number of microns of thickness. When the critical damage values are determined, the physical damage functions can be used to express the amount of time before MR\&R activities are required as a function of the concentration of acid in the environment. For example, if at a given concentration of acid the galvanized coating loses 0.5 micron of thickness each year, and the critical damage value is ten microns lost, then it will need to be replaced in 20 years.

The expected time between MR\&R activities, when combined with the cost data presented in this report, could be used in a life-cycle cost model to derive estimates of the dollar costs of repairing the damage to building components caused by acid deposition. These estimates would be expressed as the annualized cost of damage per physical unit of the component being considered. For example, damage to painted wood walls would be expressed in dollars per year per square foot of surface area to be painted, while damage to rain gutters would be expressed in dollars per year per lineal foot of guttering to be replaced. In the next subsection, the derivation of such annualized cost damage estimates will be illustrated with numerical examples.

Finally, these unit damage estimates would be combined with building materials inventory data to derive estimates of the total dollar value of acid deposition damage to buildings in the United States. The Building Inventory Worksheet being used to collect these data is presented in appendix $A$. As can be seen from the Worksheet, the information being collected in this survey will include detailed data on the areas and 1 ineal dimensions of all the major building components and on the significant materials of which they are made. These component/material combinations have been specifled so that the areas and lineal dimensions being inventoried for each combination can be directly matched with the corresponding MR\&R activities for which cost data are presented in this report. 


\subsection{Illustrations}

This subsection 11lustrates how the MR\&R activity cost data can be combined with data on the expected time between MR\&R activities in order to derive a damage estimate, in terms of annualized cost. The MR\&R activities are assumed to occur at the end of each service life of the activity. The evaluations in this section are based on the discounted annualized cost $A$ of an expenditure $C$ that is expected to be made in year N.1

$$
A=\frac{C \cdot i}{(1+d)^{N-1}}
$$

where $C=$ the estimated cost of the MR\&R activity,

$\mathrm{d}=$ the discount rate, and

$N=$ the number of years between each occurrence of the MR\&R activity (that is, the expected service life).

The first illustration concerns the cost of maintaining 10,000 square feet of galvanized steel siding. Assume that in environment $A$, the siding will require replacement every 20 years, while in the more acidic environment B it will last only 16 years. From table 3.3 , it can be seen that the average cost of installing galvanized steel siding is $\$ 2.66$ per square foot. Thus $C$, the installation cost, can be estinated at $\$ 26,600$ for 10,000 square feet. If the discount rate is ten percent, then the annualized cost is $\$ 464$ in environment $A$ and $\$ 740$ in environment $B$. Under the assumptions of this illustration, the difference of $\$ 276$ represents the cost per year of acid rain damage.

The second example examines the effects of acid rain and other pollution on the cost of painting steel buildings. The costs of two different painting systems in three different climates, called Mild, Moderate, and Severe, 2 are compared.

$1_{\text {This formula, sometimes referred to as the Uniform Sinking Fund (USF) }}$ Fomula, is taken from the American Society for Testing and Materials, "Standard Practice for Measuring Life-Cycle Costs of Buildings and Building Systems," ASTM E917-83 (Philadelphia, 1983), p. 10.

${ }^{2}$ Data on paint cost and expected service life were taken from A. H. Roebuck and G. H. Brevoort, "Coating Work Costs and Estinating," Materials Performance (January 1983), pp. 43-47. The definitions of Mild, Moderate, and Severe, also from Roebuck and Brevoort, are the following:

\footnotetext{
Mild = Rural or residential atmosphere. No appreciable industrial fumes or fallout.

Moderate $=$ Industrlal plants present. No heavy contamination of industrial fumes or fallout.

Severe $=$ Heavy industrial and chemical plant area with high level contamination of industrial fumes and fallout. Can include proximity to saltwater.
} 
Table 4.1 shows the results of calculations suggested by Roebuck and Brevoort to estimate the cost of painting a bullding for two alternative coating systems. The total cost is obtalned by adding the cost of paint to the labor cost for cleaning and painting the surface. Table 4.2 presents the data on expected service 11 fe as reported by Roebuck and Brevoort for each coating system. Using these data, and again assuming that the discount rate is ten percent, the discounted annualized cost for each system can be calculated. Table 4.3 presents these results.

Table 4.1 Application Costs of Coating Systems (1981 \$/SF)

3 Coat Vinyl SSPC6
3 Coat Latex SSPC6

Materials Cost

\begin{tabular}{lll}
\hline $\begin{array}{l}\text { Primer } \\
\text { Topcoat }\end{array}$ & 0.094 & 0.043 \\
Finish & 0.177 & 0.039 \\
Materials Total & 0.064 & 0.039 \\
Labor Cost & 0.335 & 0.121 \\
$\begin{array}{l}\text { Cleaning } \\
\text { Painting }\end{array}$ & 0.55 & 0.55 \\
Labor Total & 0.39 & 0.39 \\
Total Unit Cost & 0.940 & 0.94 \\
Cost/10,000 SF & 1.275 & 1.061 \\
& 12,750 & 10,610
\end{tabular}

Source: A. H. Roebuck and G. H. Brevoort. "Coating Work Costs and Estinating," Materials Performance (January 1983), pp. 43-47. 
Table 4.2 Expected Service Lives (Years) of Coating systems in Various Atmospheric Conditions

Mild Moderate $^{2} \quad$ Severe $^{3}$

$\begin{array}{llll}\text { Viny1, SSPC6 } & 7 & 6 & 5 \\ \text { Latex, SSPC6 } & 7 & 5 & 3\end{array}$

Source: Roebuck and Brevoort

1 Mild = Rural or residential atmosphere. No appreciatle industrial fumes or fallout.

2 Moderate $=$ Industrial plants present. No heavy contamination of industrial fumes.

3 Severe $=$ Heavy industrial and chemical plant area with high level contanination of industrial fumes and fallout. Can include proximity to saltwater.

Table 4.3 Discounted Annualized Cost (1981 $\$ / 10,000 \mathrm{SF} /$ year) for Coating Systems in Various Atmospheric Conditions (Discount Rate $=10 \%$ )

\begin{tabular}{lccc}
\hline & Mild & Moderate & Severe $^{3}$ \\
\hline Viny1, SSPC6 & 1344 & 1652 & 2088 \\
Latex, SSPC6 & 1119 & 1738 & 3205 \\
\hline
\end{tabular}

Source: Roebuck and Brevoort

$1 \mathrm{Mild}=$ Rural or residential atmosphere. No appreciable industrial

fumes or fallout.

2 Moderate $=$ Industrial plants present. No heavy contamination of Industrial

3 Severe $=$ fumes. contamination of Industrial fumes and fallout. Can Include proximity to saltwater. 
The discounted annualized cost estimates shown in table 4.3 confirm the conmon-sense notion that different paints are better in different environinents. Because latex paint has considerably lower application costs than vinyl $(\$ 10,610$ versus $\$ 12,750)$ and the same expected service life of 7 years in the Mild climate, latex turns out to be the more economical coating in tems of discounted annualized cost $(\$ 1,119$ versus $\$ 1,344)$. In the Moderate environment, however, the longer service life of vinyl paint offsets the lower application cost of latex paint, making vinyl the preferred coating in terins of discounted annualized cost $(\$ 1,652$ versus $\$ 1,738)$. The advantage of vinyl in tems of longer service life becomes even more pronounced in the Severe environment ( 5 versus 3 years). As a result, the discounted annualized cost of vinyl is much lower than that of latex $(\$ 2,088$ versus $\$ 3,205)$. Such results will, in general, be sensitive to the discount rate used in the analysis. In this example, however, which coating system is the more economical does not change in any of the three environments for discount rates between two and twenty percent.

Calculations such as these not only can help to select the optimal paint in a given environment, but also can be used to detemine the economic effects of a changing environment. For instance, if acid rain causes a once Mild climate (where latex paint is typically used) to become Moderate, the discounted annualized cost of maintaining the latex paint on 10,000 square feet of surface rises by $\$ 619(=\$ 1,738-\$ 1,119)$. The substitution of vinyl paint in the Moderate environment would reduce this cost increase to $\$ 533$ $(=\$ 1,652-\$ 1,119)$. 
5. SUMMARY, CONCLUSIONS, AND RESEARCH NEEDS

\subsection{Summary and Conclusions}

This report has presented and documented life-cycle cost data for the most economically significant building materials suspected of being damaged by exposure to environmental acid deposition. The data include estimates of the costs of 24 building maintenance, repair, and replacement (MR\&R) activities expected to be required more often in an acid environinent. The cost data are organized by bullding component and the material of which the component is made. As explained in section 1, the selection of the components and naterials to be included within the scope of this study was based on the economic importance of expected damage to the components and materials. The bullding components selected under this criterion were walls, roofs, fences, rain gutters, and downspouts. The materials selected include paint, limestone, marble, galvanized steel, copper, and masonry mortar.

A literature search was conducted for sources of useful cost data on the MR\&R activities relevant to these building components and materials. The complete results of this search are given in the Cited and the Other References listed below. Six of these references were selected as the sources for the data base because they are widely accepted as cost estimation manuals in the construction industry, they are regularly updated, and they are basically consistent with one another. A detailed description of each of these published cost data sources was provided in section 2.

The search of the six published data sources yielded 360 cost estimates. These estimates were initially organized into 14 general MR\&R activity categories. Technical specifications were used to divide these categories further into 26 groups. The technique of analysis of variance was then used to establish the final 24 MR\&R activity groups. The results of this data collection and organization effort were summarized in section 3 and are presented in detail in appendix B. Both the arithmetic mean and the median were presented for each of the 24 activities. The mean and the median are alnost equal in most cases, which indicates that distributions are generally symmetric. The largest percentage difference between the mean and median occurred in the case of galvanized rain gutters, where the difference was 26 percent of che mean. All but five of the groups had differences of less than 10 percent.

Regression analysis was used to examine variation in the cost estimates within 11 of the MR\&R activity groups. For nine of the 11 data sets analyzed, the estinated slope coefficients have algebraic signs that make economic sense. Of these, six have R-squared values indicating that more than 25 percent of the variation in cost is explained by the independent variable. Four of the six have $\mathrm{R}$-squared values in excess of 50 percent. 
The relationship of these cost data to other data being developed as part of various research efforts within the Materials Effects Task Group was explained in section 4. These other data include the materials damage functions, the data on the estimated effects of acid deposition damage on the frequency of MR\&R activities, and the bullding materials inventory data. Section 4 also 11 lustrated how the life-cycle cost data presented in this report can be combined with these other data to arrive at an estimate of the annualized dollar cost of acid precipitation damage to bulldings.

\subsection{Future Research Needs}

Two major research efforts remain as natural extensions of this Iife-cycle cost data project. The first is to expand the cost data base to cover more materials, components, and MR\&R activities. These could include building-related components and materials assoclated with several new damage functions expected to be developed, such as concrete, nonmetal roofing material, bullding sealants, and roof-mounted equipment, as well as components from other structures such as guard rails and transmission towers. Much of the cost data necessary to include the new bullding-related materials and components could be obtained from the published data sources already identified, although inclusion of the nonbullding structures would likely require new sources.

The other effort that should be undertaken is to make the data more accessible to other researchers interested in the assessment of acid deposition damage to common bullding materials. This goal could be served by the development of a structure for the data base that permits direct data transfer to other computer systems. Another possibility is to develop a system for automating the adjustments to the cost data described in appendices $C$ and D. Such a system could include the adjustments necessary to take into account geographic location, inflation (changes in the base period), labor type, project type, and economies of scale. 


\section{REFERENCES CITED}

American Soclety for Testing and Mater1als. "Standard Practice for Measuring Life Cycle Costs of Bulldings and Bullding Systems." ASTM E917-83. Ph1ladelph1a, PA, 1983.

E. H. Boeckh Co. Underwriter's Valuation Manual. Milwaukee, WI: American Appraisal Assoclates, Inc., 1984.

Building Cost File, Inc. The 1984 Berger Building \& Design Cost File (Vol. 1: General Construction Trades - Unit Prices). Hicksvilie, NY, 1984.

Hogben, David, Sally T. Peavy and Ruth N. Varner. OMNITAB II User's Reference Manual (NBS Technical Note 552). Washington, D.C.: J.S. Government Printing office, 1971.

McGraw-Hill Cost Information Systems. 1984 Dodge Construction Systems Costs (1984 Construction Cost Information, Vol. 1). Princeton, NJ, 1983.

McGraw-Hill Cost Information Systems. 1984 Dodge Manual for Building Construction Pricing and Scheduling (1984 Construction Cost Information, Vol. 2, 19th Annual Edition). Princeton, NJ, 1983.

McGraw-Hi11, Inc. Engineering News-Record. New York. Weekly.

Robert Snow Means Company, Inc. Building Construction Cost Data 1984. Kingston, MA, 1984.

Robert Snow Means Company, Inc. Repair and Remodeling Cost Data: Commercial/Residential 1984 (5th Annual Edition). Kingston, MA, 1984.

Robert Snow Means Company, Inc. Residential/Light Commercial Cost Data 1984 (3rd Annual Edition). Kingston, MA, 1984.

Roebuck, A. H. and G. H. Brevoort. "Coating Work Costs and Estimating." Materials Performance (January 1983), pp. 43-47.

U.S. Department of Commerce, Bureau of Economic Analysis. Survey of Current Business. Washington, D.C.: U.S. Government Printing Office. Monthly.

U.S. Department of Commerce, Bureau of Industrial Econoinics. Construction Review. Washington, D.C.: U.S. Government Printing of fice. Bi-Monthly.

U.S. Department of Commerce, National Bureau of Standards. The International System of Units (SI) (NBS Special Publication 330, 1977 Edition). Washington, D.C.: U.S. Government Printing of fice, 1977. 
OTHER DATA SOURCES

Bennett, L.H. et al. Economic Effects of Metallic Corrosion in the United States, Part I: A Report to Congress by the National Bureau of Standards. Washington, D.C.: U. S. Government Printing Office, 1978.

Haynie, Fred H. "Deterioration of Marble." Durability of Building Materials, Vol. 1, No. 3 (January 1983), pp. 241-254.

McGraw-Hill, Inc. Sweet's Catalog File. New York: Sweet's Division, McGraw-Hi11. Annual.

Morcillo, M. "Minimum Film Thickness for Protection of Hot-Rolled Steel: Results after 23 Years of Exposure at Kure Beach, North Carolina." New Concepts for Coating Protection of Steel Structures ASTM STP 84T, D. M. Berger and R. F. Wint, eds. Philadelphia: American Society for Testing and Materials, 1984, pp. 95-112.

Payer, J. H. et al. Economic Effects of Metallic Corrosion in the United States - Appendix B, Part II: A Report to NBS by Battelle Columbus Laboratories. Washington, D.C.: U.S. Government Printing Office, 1978.

Pereira, Percival E., ed. Dodge Building Cost Calculator \& Valuation Guide (Edition 41). New York: McGraw-Hi11, 1981.

Robert Snow Means Company, Inc. Means Systems Costs 1984. Kingston, MA, 1984.

Sarviel, Ed. Construction Estimating. California: Craftsman Book Company, 1981.

Sereda, P.J., and G. G. Litran, eds. Durability of Building Materials and Components (Proceedings of the First International Conference, ASTM STP 691). Philadelphia: American Society for Testing and Materials, 1980.

Spradlin, William H., Jr. The Building Estinator's Reference Book. Chicago: Frank R. Walker Company, 1982. 
APPENDIX A. BUILDING INVENTORY WORKSHEET FOR PILOT STUDY $(1 / 3 / 84)$

1. Bullding Identifiers:

1.1 State County_ Tract/MCD

Land use class

Photo ID

Street address

1.2 UTM Coord.

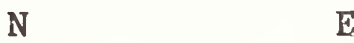

Geog Coord. lat $N$ long $\mathrm{W}$

USGS quad, date

2. Building Description:

2.1 Type of St ructure (Check One)

ResidentLal Building

$$
\begin{aligned}
& \text { Housing Unit } \\
& 1 \text { Unit Detached } \\
& 1 \text { Unit Attached } \\
& 2 \text { Units } \\
& 3 \text { and } 4 \text { Units } \\
& 5 \text { to } 9 \text { Units } \\
& 10 \text { to } 19 \text { Units } \\
& 20 \text { to } 49 \text { Units } \\
& 50 \text { or More Inits }
\end{aligned}
$$

Nonhousekeeping (1.e., hotels, motels, dornitorles, fraternity and sorority houses, nurses homes, and similar facilittes) 
Nonresidential Bullding

Offlce Bu1lding

Other Commerclal

Industrial

Hospltal or Inst1tutional

Religious

Educational

Other Nonresidential

Farm (nonresidential)

Other (Identify structure

Cannot Identify

2.2 Gross Lot Dimensions, including extension to center of street (f).

2.3 Sketch Building Exterior Plan, indicating (1) dimensions of building exterior ( $f$ ) and (2) the location of horizontal guttering runs with dashed lines.

2.4 Number of Stories, excluding foundation

2.5 Average Wall Height (f)

(from grade to roof)

2.6 Approximate Age of Structure (yrs) 


\section{Materials Inventory:}

3.1 Walls

(Indicate type of wall by entering the percentages of exterior wall surface area beside each type. Include areas of glazing and doorway under their proper material types.)

3.1.1 Painted Walis

(Indicate percentages for each substrate material.)

3.1.1.1 Wood (excl. stained)

3.1.1.2 Steel

3.1.1.3 Alumi num

3.1 .1 .4 Masonry

3.1 .1 .5 Concrete

3.1.1.6 Stucco

3.1.1.7 Other (Identify Material

3.1.1.8 Cannot Identify

TOTAL

\subsubsection{Bare Wa11s}

(Indicate percentages for each surface materia1.)
Percent (\%) of Wall Area of

Each Horizontal Section

Founda- 1st All Stories Percent (\%) of

tion Story Above 1st Total Wall Area
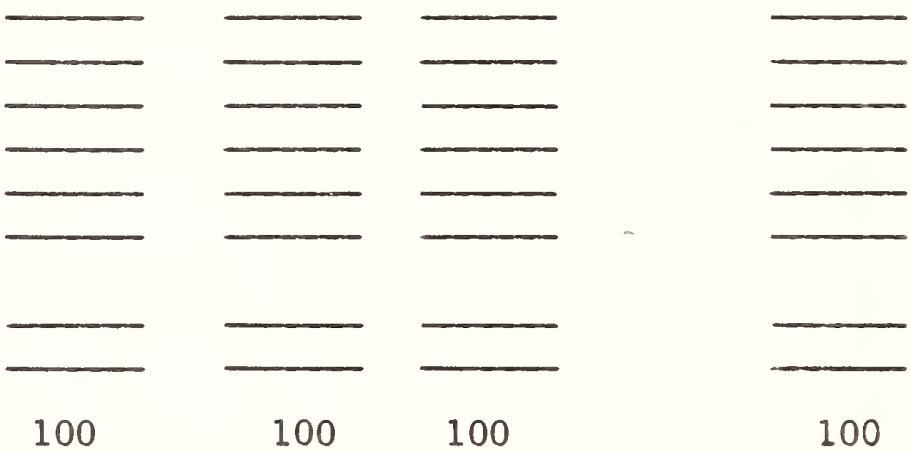

Percent (\%) of Wall Area of Each Horizontal Section

Founda- lst Al1 Stories
tion Story Above lst

Percent (\%) of Total Wall Area

3.1.2.1 Masonry (Check

Brick

Bl ock or

Field $\overline{\text { Stone }}$

3.1.2.2 Concrete

3.1.2.3 Marble

3.1.2.4 Limestone

3.1.2.5 Granite

3.1.2.6 Galvanized Steel

3.1.2.7 Wood (incl. stained)

3.1.2.8 Glass

3.1 .2 .9 Viny 1

3.1 .2 .10 other (Identify

Material

3.1.2.11 Cannot Identify

TOTAL

Story Above lst
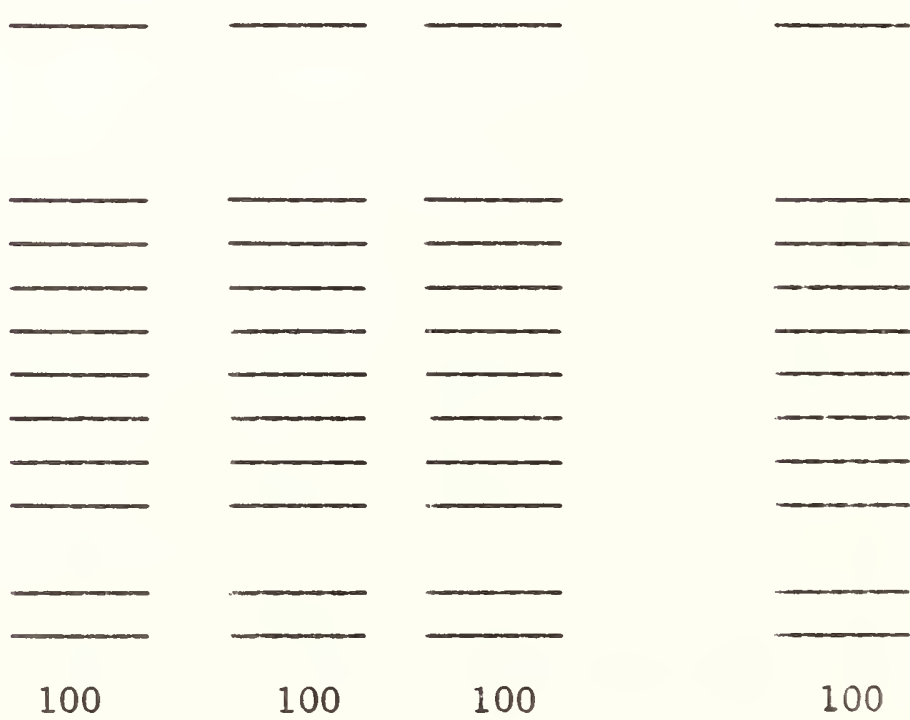


\subsection{Roof 8}

\subsubsection{Configuration: Check whether}

sloped or Flat

3.2.2 Area of Exposed Surface $\left(f^{2}\right)$

3.2.3 Exposed Roof Material

(Check Predominant Material)

3.2.3.1 Asphalt Shingle

3.2 .3 .2 Wood

3.2.3.3 Painted Metal

3.2.3.4 Bare Galvanized

3.2 .3 .5 Tile

3.2.3.6 Slate

3.2 .3 .7 Copper

3.2.3.8 Other (Identify Material

3.2.3.9 Cannot Identify

3.2.4 Roof-Mounted Apparatus

Material

[Enter material: painted, bare galvanized, bare aluminum, other

Number of (identify material), or cannot Items identify. For skylights, enter framing material only.]

3.2.4.1 Vents, Flues, Stacks

3.2.4.2 Skylights

3.2.4.3 Flashing

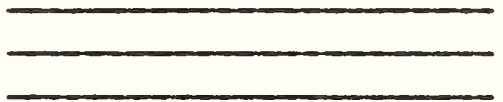

\subsection{Chimneys}

3.3.1 Exposed Surface Area Above Roof ( $\mathrm{f}^{2}$ )

3.3.2 Enter Material: Painted, Brick, Stone, Other (Identify Material), or Cannot Identify.

3.4 Rain Gutters

3.4.1 Check if No Gutters

3.4.2 Horizontal Runs

Enter Material: Bare Galvanized, Vinyl, Painted, Copper, Other (Identify Material), or Cannot Identify 
3.4.3 Downspouts

(Enter sum of helghts for all downspouts.)

\section{Downspouts}

(f)

3.4.3.1 Bare Galvanized

3.4.3.2 Viny 1

3.4.3.3 Painted

3.4.3.4 Copper

3.4.3.5 Other (Identify Material

3.4.3.6 Cannot Identify

3.5 Fences

(Enter length and height.)

Length ( $f$ )

Height (f)

3.5.1 Bare Galvanized Chain Link

3.5.2 Bare Galvanized Wire Mesh

3.5.3 Painted

(Enter percent of area that is solid $\%$.)

3.5.4 Masonry (Check Brick

Bl ock

Field Stone
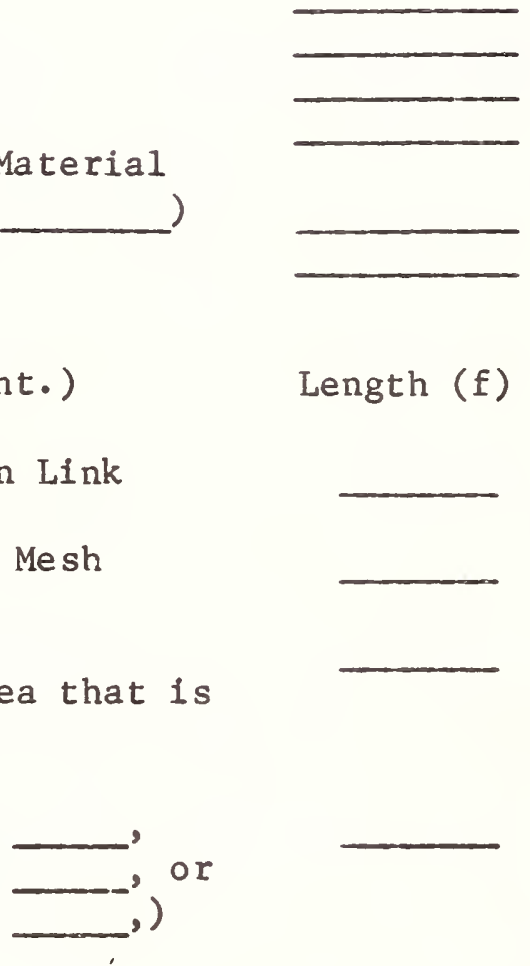

\section{Cight (f)}
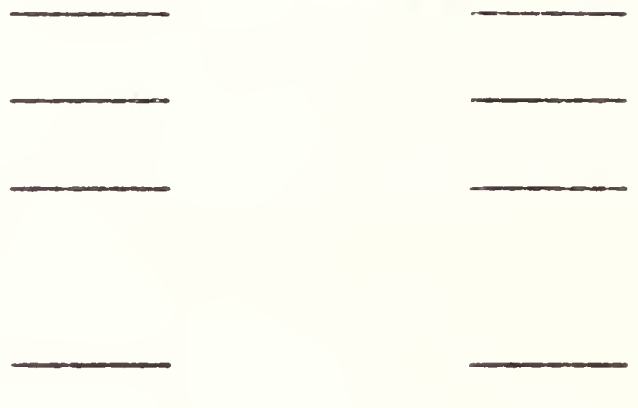

3.5.5 Unpainted Wood

3.5.6 Other (Identify Material

3.5.7 Cannot Identify

3. 6 Outdoor Accessories. Describe all other accessories (e.g., sheds, storage tanks, handrails, poles, mailboxes, benches, signs, ornamental building features) of the following materials: painted, bare galvanized, bare aluminum, bare steel, copper, concrete, ornamental metal.

Accessory

Material
Exposed Surface Area $\left(f^{2}\right.$ ) 
This appendix presents the entire data base of individual cost estinates on which the summary statistics given in section 3 are based. The cost estimates are organized according to the 24 groups of MR\&R activities used in table 3.3. For each activity group, a separate table presents the individual cost estimates ranked in ascending order of cost, with the rank order given in the far left column. The next column(s) to the right present speclal characteristic(s) of the cost estinate that were avallable for most of the estinates in that activity group. If the special characteristic was not avallable for a particular cost estinate, the code NS (for Not Specified) is given. For some activities there are two such special characteristics. The cost estinate itself stated in 1984 dollars per unit of measurement is given in the next column. The unit of measurement used is given in the heading of this column. The column to the right of the cost estimate indicates the published data source of the estimate using a two- or three-letter code to represent one of the six cost data sources discussed in section 2. For reference, the code and the full bibliographic citation of each data source is given in table B.I. 
Table B.1 Identification Codes Used for Data Sources in the Data Base

Code

Data Source

BER Building Cost File, Inc. The 1984 Berger Building \& Design Cost File (Vol. 1: General Construction Trades - Unit Prices). Hicksville, NY: 1984.

BOE E. H. Boeckh Co. Underwriter's Valuation Manual. Milwaukee, WI: American Appraisal Associates, Inc., 1984.

DS McGraw-Hil1 Cost Information Systems. Dodge Construction Systems Costs 1984 (1984 Construction Cost Information, Vo1. 1). Princeton, NJ: 1983.

DP McGraw-Hill Cost Information Systems. 1984 Dodge Manual for Building Construction Pricing and Scheduling, 19th Annual Edition (1984 Construction Cost Information, Vol. 2). Princeton, NJ: 1983.

MRR Robert Snow Means Company, Inc. Repair and Remodeling Cost Data: Commercial/Residential 1984, 5th Annual Edition. Kingston, MA: 1984.

MRC Robert Snow Means Company, Inc. Residential/Light Commerclal Cost Data 1984, 3rd Annual Edition. Kingston, MA: 1984. 
Table B.2

PAINTING WOOD WALLS

ITEM PAINT NUM OF COST PER SOURCE PAGE

SPECIFICATIONS

NUM TYPE COATS COAT (\$/SF)

\begin{tabular}{|c|c|c|c|c|c|c|}
\hline 1 & LAT & 2 & $\$ 0.10$ & $D P$ & $15 !$ & AIRLESS SPRAY \\
\hline 2 & LAT & 2 & $\$ 0.11$ & $D P$ & 151 & SPRAY \\
\hline 3 & LAT & 1 & $\$ 0.13$ & $D P$ & 151 & AIRLESS SPRAY \\
\hline 4 & LAT & 1 & $\$ 0.14$ & $D P$ & 151 & SPRAY \\
\hline 5 & VLT & 3 & $\$ 0.15$ & BER & 130 & WOOD SIDING \\
\hline 6 & NS & 3 & $\$ 0.17$ & DS & 69 & BOARD \& BATTEN \\
\hline 7 & VLT & 3 & $\$ 0.17$ & BER & 130 & WOOD SHINGLES \\
\hline 8 & OIL & 3 & $\$ 0.18$ & $D P$ & 151 & ROLL \\
\hline 9 & NS & 3 & $\$ 0.18$ & DS & 69 & PLYHOOD OR CEDAR SIDING \\
\hline 10 & ENA & 3 & $\$ 0.20$ & BER & 130 & WOOD SIDING \\
\hline 11 & $0 ! 1$ & 2 & $\$ 0.21$ & $D P$ & 151 & ROLL \\
\hline 12 & ENA & 3 & $\$ 0.21$ & BER & 130 & WOOD SHINGLES \\
\hline 13 & OIL & 3 & $\$ 0.25$ & $D P$ & 151 & BRUSH \\
\hline 14 & OIL & 1 & $\$ 0.26$ & $D P$ & 151 & ROLL \\
\hline 15 & OIL & 2 & $\$ 0.27$ & DP & 151 & BRUSH \\
\hline 16 & OIL & 1 & $\$ 0.32$ & $D P$ & 151 & BRUSH \\
\hline 17 & NS & 2 & $\$ 0.33$ & MRF & 175 & PUTTY \\
\hline 18 & NS & 1 & $\$ 0.47$ & MRR & 565 & PUTTY \\
\hline
\end{tabular}

PAINT TYPES: LAT = LATEX, ALT = ACRYLIC LATEX, VLT = VINYL LATEX

$E P Y=E P O X Y, E N A=E N A M E L, O I L=O I L, N S=$ NOT SPECIFIED 
Table B.3

PAINTING MASONRY WALLS

$\begin{array}{lcccccc}\text { ITEM } & \text { PAINT NUM OF COST PER } & \text { SOURCE } & \text { PAGE } & \text { SPECIFICATIONS } \\ \text { NUM } & \text { TYPE } & \text { COATS } & \text { COAT }(\$ / S F) & & & \\ 1 & \text { VLT } & 1 & \$ 0.09 & \text { BER } & 130 & \text { FINISH COAT } \\ 2 & \text { VLT } & 2 & \$ 0.18 & \text { BER } & 130 & \\ 3 & \text { VLT } & 1 & \$ 0.18 & \text { BER } & 130 & \text { SEALER COAT } \\ 4 & \text { ENA } & 1 & \$ 0.22 & \text { BER } & 130 & \text { HIGH GLOSS ENAMEL, FINISH COAT } \\ 5 & \text { ENA } & 2 & \$ 0.24 & \text { BER } & 130 & \text { HIGH GLOSS ENAMEL } \\ 6 & \text { EPY } & 3 & \$ 0.29 & \text { BER } & 131 \text { RESIN/ACRYLIC, SPACKLE FINISH } \\ 7 & \text { ENA } & 1 & \$ 0.31 & \text { BER } & 130 & \text { HIGH GLOSS ENAMEL, SEALER COAT } \\ 8 & \text { EFY } & 3 & \$ 0.35 & \text { BER } & 131 \text { RESIN/ACRYLIC, SPACKLE FINISH, SPRAY } \\ 9 & \text { NS } & 2 & \$ 0.39 & \text { MRR } & 175 & \text { BRUSHWORK, BRICK } \\ 10 & \text { NS } & 2 & \$ 0.46 & \text { MRR } & 175 & \text { BRUSHWORK, BLOCK, FILLER + } 2 \text { COATS } \\ 11 & \text { NS } & 1 & \$ 0.58 & \text { MRR } & 175 & \text { BRUSHWORK, BRICK } \\ 12 & \text { NS } & 1 & \$ 0.71 & \text { MRR } & 175 & \text { BRUSHWORK, BLOCK, FILLER + } 1 \text { COAT }\end{array}$

PAINT TYPES: LAT = LATEX, ALT = ACRYLIC LATEX, VLT = VINYL LATEX

EPY $=$ EPOXY, ENA $=$ ENAMEL, OIL $=$ OIL, NS $=$ NOT SPECIFIED 
Table B.4

PAINTING CONCRETE WALLS

\begin{tabular}{|c|c|c|c|c|c|c|}
\hline $\begin{array}{l}\text { ITEM } \\
\text { NUM }\end{array}$ & $\begin{array}{l}\text { PAINT } \\
\text { TYFE }\end{array}$ & $\begin{array}{l}\text { NUM OF } \\
\text { COATS }\end{array}$ & $\begin{array}{c}\text { COST PER } \\
\text { COAT }(\$ / S F)\end{array}$ & SOURCE & PAGE & SPECIFICATIONS \\
\hline 1 & VLT & 3 & $\$ 0.15$ & BER & 130 & \\
\hline 2 & ENA & 3 & $\$ 0.20$ & BER & 130 & HIGH GLOSS ENAMEL \\
\hline 3 & VLT & 1 & $\$ 0.23$ & BER & 130 & FINISH COAT \\
\hline 4 & EPY & 3 & $\$ 0.29$ & BER & 131 & RESIN/ACRYLIC, SPACKLE FINISH \\
\hline 5 & EPY & 3 & $\$ 0.35$ & BER & 131 & RESIN/ACRYLIC, SPACKLE FINISH, SPRAY \\
\hline 6 & ENA & 1 & $\$ 0.36$ & BER & 130 & HIGH GLOSS ENAMEL, FINISH COAT \\
\hline 7 & NS & 2 & $\$ 0.39$ & MRR & 175 & BRUSHWORK \\
\hline 8 & NS & 1 & $\$ 0.58$ & MRR & 175 & BRUSHWORK \\
\hline
\end{tabular}

PAINT TYPES: LAT = LATEX, ALT = ACRYLIC LATEX, VLT = VINYL LATEX

$E P Y=E P O X Y, E N A=E N A M E L, O I L=O I L, N S=$ NOT SPECIFIED 
Table B.5

PAINTING STIUCCO WALLS

ITEM PAINT NUM OF COST PER SOURCE PAGE SPECIFICATIONS NUM TYFE COATS COAT $(\$ / S F)$

$\begin{array}{lllllll}1 & \text { LAT } & 2 & \$ 0.12 & \text { DP } & 151 & \text { SPRAY, MEDIUM TEXTURE STUCCO } \\ 2 & \text { LAT } & 1 & \$ 0.13 & \text { DP } & 151 \text { SPRAY, MEDIUM TEXTURE STUCCO } \\ 3 & \text { LAT } & 2 & \$ 0.13 & \text { DP } & 151 \text { ROLL, MEDIUM TEXTURE STUCCO } \\ 4 & \text { LAT } & 2 & \$ 0.16 & \text { DP } & 151 \text { BRUSH, MEDIUM TEXTURE STUCCO } \\ 5 & \text { LAT } & 1 & \$ 0.16 & \text { DP } & 151 \text { ROLL, MEDIUM TEXTURE STUCCO } \\ 6 & N S & 3 & \$ 0.17 & \text { DS } & 71 & \\ 7 & N S & 3 & \$ 0.18 & \text { DS } & 72 & \text { BLOCK \& STUCCO SYSTEM } \\ 8 & \text { LAT } & 1 & \$ 0.22 & \text { DP } & 151 \text { BRUSH, MEDIUM TEXTURE STUCCO } \\ 9 & \text { VLT } & 1 & \$ 0.33 & \text { BER } & 130 & \text { FINISH COAT } \\ 10 & \text { ENA } & 1 & \$ 0.46 & \text { BER } & 130 & \text { FINISH COAT }\end{array}$

PAINT TYPES: LAT = LATEX, ALT = ACRYLIC LATEX, VLT = VINYL LATEX EPY $=$ EPOXY, ENA $=$ ENAMEL, OIL $=$ OIL, NS = NOT SPECIFIED 
Table B.6

PAINTING METAL WALLS

ITEM PAINT NUM OF COST PER SOURCE PAGE
NUM TYPE COATS COAT (\$/SF)

NUM TYPE COATS COAT $(\$ / S F)$

$\begin{array}{lllllll}1 & \text { ALT } & 2 & \$ 0.09 & \text { DP } & 151 & \text { CQRRUGATED METAL SIDING, SPRAY } \\ 2 & \text { ALT } & 1 & \$ 0.12 & \text { DP } & 151 \text { CORRUGATED METAL SIDING, SPRAY }\end{array}$

PAINT TYPES: LAT = LATEX, ALT = ACRYLIC LATEX, VLT = VINYL LATEX

EPY $=$ EPOXY, ENA $=$ ENAMEL, OIL = OIL, NS = NOT SPECIFIED 
Table B.7

GALVANIZED STEEL SIDING

ITEM GAUEE COST (\$/SF) SOURCE PAGE SPECIFICATIONS

$\begin{array}{llllll}1 & 26 & \$ 1.46 & \text { BER } & 82 & \text { WITH UNDERLAYMENT, SHINGLES } \\ 2 & 26 & \$ 1.47 & \text { DS } & 78 & \text { EALV IRON SIDING, CORRUGATED, UNINSUL } \\ 3 & 24 & \$ 1.50 & \text { BER } & 82 & \text { WITH UNDERLAYMENT, SHINGLES } \\ 4 & 24 & \$ 1.65 & \text { DS } & 78 & \text { GALV IRON SIDING, CORRUGATED, UNINSUL } \\ 5 & 29 & \$ 1.71 & \text { MRR } & 119 & \text { CORRUGATED OR RIBBED } \\ 6 & 26 & \$ 1.93 & \text { MRR } & 119 & \text { CORRUGATED OR RIBBED } \\ 7 & 26 & \$ 1.99 & \text { BER } & 82 & \text { WITH UNDERLAYMENT, SHINGLES, BOND } \\ 8 & 24 & \$ 2.13 & \text { BER } & 82 & \text { WITH UNDERLAYMENT, SHINGLES, BOND } \\ 9 & 24 & \$ 2.23 & \text { MRR } & 119 & \text { CORRUGATED OR RIBBED } \\ 0 & 22 & \$ 2.42 & \text { MRR } & 119 & \text { CORRUGATED OR RIBBED } \\ 1 & 20 & \$ 2.62 & \text { MRR } & 119 & \text { CORRUGATED OR RIBBED } \\ 2 & 26 & \$ 3.95 & \text { BER } & 82 & \text { PREFORMED GALV METAL SIDING, UNINSUL } \\ 3 & 24 & \$ 4.02 & \text { BER } & 82 & \text { PREFORMED GALV METAL SIDING, UNINSUL } \\ 4 & 22 & \$ 4.13 & \text { BER } & 82 & \text { PREFORMED GALV METAL SIDING,UNINSUL } \\ 5 & 20 & \$ 4.49 & \text { BER } & 82 & \text { PREFORMED GALV METAL SIDING,UNINSUL } \\ 6 & 18 & \$ 4.88 & \text { BER } & 82 & \text { PREFORMED GALV METAL SIDING, UNINSUL }\end{array}$


Table B.8

INDIANA LIMESTONE WALLS

ITEM THCK COST SOURCE PAGE

(IN) $(\$ / S F)$

SPECIFICATIONS

4.0 8.11 BER 57 UP TO 50 SF, INDIANA LIMESTONE FACING PANEL, MODULAR DESIGM, LT TEXTURE, BLENDED COLORS

$4.0 \quad 8.43$ BER 57 UP TO 50 SF, INDIANA LIMESTONE FACING PANEL, MODULLAR DESIGN, DEEP TEXTURE, BLENDED COLORS

4.08 .64 BER 57 UP TO 50 SF, INDIANA LIMESTONE FACING PANEL, MODULAR DESIGN, MEDIUM TEXTURE, BLENDED COLORS

4.58 .74 BER 57 UP TO 60 SF, INDIANA LIMESTONE FACING PANEL, MODULAR DESIGN,LT TEXTURE, BLENDED COLORS

4.09 .00 BER 57 UP TO 50 SF, INDIANA LIMESTONE FACING PANEL, MODULAR DESIGN,LT TEXTURE, PURE COLDR

4.59 .06 BER 57 UP TO 60 SF, INDIANA LIMESTONE FACING PANEL, MODULAR DESIGN, DEEP TEXTURE, BLENDED COLORS

5.09 .09 BER 57 UP TO 70 SF, INDIANA LIMESTONE FACING PANEL, MODULAR DESIGN,LT TEXTURE, BLENDED COLORS

4.59 .27 BER 57 UP TO 60 SF, INDIANA LIMESTONE FACING PANEL, MODULAR DESIGN, MEDIUM TEXTURE, BLENDED COLORS

5.09 .41 BER 57 UP TO 70 SF, INDIANA LIMESTONE FACING PANEL, MODULAR DESIGN, DEEP TEXTURE, BLENDED COLORS

5.09 .62 BER 57 UP TO 70 SF, INDIANA LIMESTONE FACING PANEL, MODULAR DESIEN, MEDIUM TEXTURE, BLENDED COLORS

4.59 .63 BER 57 UP TO 60 SF, INDIANA LIMESTONE FACING PANEL, MODULAR DESIGN,LT TEXTURE, PURE COLOR

5.09 .98 BER 57 UP TO 70 SF, INDIANA LIMESTONE FACING PANEL, MODULAR DESIGN,LT TEXTURE, PURE COLOR

2.012 .34 DP 66 FACING PANELS, INDIANA LIMESTONE, STANDARD

2.012 .99 DP 66 FACING PANELS, INDIANA LIMESTONE, SELECT

4.014 .35 BER 57 ASHLAR VENEER, AVERAGE, INDIANA LIMESTONE, CUSTOM DESIGN,LIGHT TEXTURE, MEDIAN QUALITY \& COST

3.014 .96 DP 66 FACING PANELS, INDIANA LIMESTONE, STANDARD

3.016 .00 DP 66 FACING PANELS, INDIANA LIMESTONE, SELECT

4.0 16.13 BER 57 ASHLAR VENEER, HIGH QUALITY GRADE, INDIANA LIMESTONE, CUSTOM, LIGHT TEXTURES

2.017 .36 BER 57 UP TO 15 SF, INDIANA LIMESTONE FACING PANEL, CUSTOM DESIGN, LT TEXTURE, MEDIAN QUALITY \& COST

4.017 .37 DP 66 FACING PANELS, INDIANA LIMESTONE, SELECT

2.017 .80 BER 57 UP TO 15 SF, INDIANA LIMESTONE FACING PANEL, CUSTOM DESIGN, MEDIUM TEXTURE, MEDian QUALITY \& COST

3.018 .23 BER 57

2.018 .35 BER 57

UP TO 32 SF, INDIANA LIMESTONE FACING PANEL, CUSTOM DESIGN,LT TEXTURE, MEDIAN QUALITY \& COST

UP TO 15 SF, INDIANA LIMESTONE FACING PANEL, CUSTOM DESIGN, DEEP TEXTURE, MEDIAN QUALITY \& COST

4.018 .55 DP 66

FACING PANELS, INDIANA LIMESTONE, STANDARD

3.018 .67 BER 57

UP TO 32 SF, INDIANA LIMESTONE FACING PANEL, CUSTOM DESIGN, MEDIUM TEXTURE, MEDIAN QUALITY \& COST

3.019 .22 BER 57

UP TO 32 SF, INDIANA LIMESTONE FACING PANEL, CUSTOM DESIGN, DEEP TEXTURE, MEDIAN QUALITY \& COST

2.019 .73 BER 57

UP TO 15 SF, INDIANA LIMESTONE FACING PANEL, CUSTOM DESIGN,LT TEXTURE, HIGH QUALITY GRADE

4.019 .83 BER 57

UP TO 50 SF, INDIANA LIMESTONE FACING PANEL, CUSTOM DESIGN,LT TEXTURE, MEDIAN QUALITY \& COST

4.020 .27 BER 57

UP TO 50 SF, INDIANA LIMESTONE FACING PANEL, CUSTOM DESIGN, MEDIUM TEXTURE, MEDIAN QUALITY \& COST

4.020 .82 BER 57

UP TO 50 SF, INDIANA LIMESTONE FACING PANEL, CUSTOM DESIGN,DEEP TEXTURE, MEDIAN QUALITY \& COST

3.020 .84 BER 57

UP TO 32 SF, INDIANA LIMESTONE FACING PANEL, CUSTOM DESIGN,LT TEXTURE, HIGH QUALITY GRADE

5.021 .15 BER 57

UP TO 65 SF, INDIANA LIMESTONE FACING PANEL, CUSTOM DESIGN,LT TEXTURE, MEDIAN QUALITY \& COST

6.021 .55 BER 57

UP TO 70 SF, INDIANA LIMESTONE FACING PANEL, CUSTOM DESIGN, LT TEXTURE, MEDIAN QUALITY \& COST

5.021 .59 BER 57

UP TO 65 SF, INDIANA LIMESTONE FACING PANEL, CUSTOM DESIGN, MEDIUM TEXTURE, MEDIAN QUALITY \& COST

6.021 .99 BER 57 UP TO 70 SF, INDIANA LIMESTONE FACING PANEL,CUSTOM DESIGN, MEDIUM TEXTURE, MEDIAN QUALITY \& COST

5.022 .14 BER 57 UP TO 65 SF, INDIANA LIMESTONE FACING PANEL,CUSTOM DESIGN,DEEP TEXTURE, MEDIAN QUALITY \& COST

6.022 .54 BER 57 UP TO 70 SF, INDIANA LIMESTONE FACING PANEL,CUSTOM DESIGN, DEEP TEXTURE, MEDIAN QUALITY \& COST

4.022 .75 BER 57 UP TO 50 SF, INDIANA LIMESTONE FACING PANEL, CUSTOM DESIGN,LT TEXTURE, HIGH QUALITY GRADE

5.024 .23 BER 57 UP TO 65 SF, INDIANA LIMESTONE FACING PANEL, CUSTOM DESIGN, LT TEXTURE, HIGH QUALITY GRADE

406.024 .76 BER 57 UP TO 70 SF, INDIANA LIMESTONE FACING PANEL, CUSTOM DESIGN, LT TEXTURE, HIGH QUALITY GRADE 
Table B. 9

ALABAMA LIMEGTONE WALLS

ITEM THCK COST SOURCE PAGE

SPECIFICATIONS

(IN) $(\$ /$ SF)

2.019 .09 DP 66 FACING PANELS, ALABAMA LIMESTONE

4.0 19.74 BER 57 ASHLAR VEMEER, MEDIAN QUALITY GRADE, ALABAMA LIMESTONE, CUSTOM, LIGHT TEXTURES

3.022 .31 DP 66 FACING PANELS, ALABAMA LIMESTONE

2.024 .54 BER 57 UF TO 15 SF, ALABAMA LIMESTONE FACING PANEL,CUSTOM DESIGN,LT TEXTURE, MEDIAN QUALITY \& COST

3.026 .15 BER 57 UP TO 32 SF, ALABAMA LIMESTONE FACING PANEL, CUSTOM DESIGN,LT TEXTURE, MEDIAN QUALITY \& COST

4.026 .56 DP 66 FACING PANELS, ALABAMA LIMESTONE

4.028 .67 BER 57 UP TO 5O SF, ALABAMA LiMESTONE FACING PANEL, CUSTOM DESIGN,LT TEXTURE, MEDiAN QUALITY \& COST

5.030 .49 BER 57 UP TO 65 SF,ALABAMA LIMESTONE FACING PANEL,CUSTOM DESIGN,LT TEXTURE, MEDIAN QUALITY \& COST

6.0 31.29 BER 57 UP TO 70 SF, ALABAMA LIMESTONE FACING PANEL, CUSTOM DESIGN,LT TEXTURE, MEDIAN QUALITY \& COST 
Table B.10

OTHER LIMESTONE HALLS

ITEM THCK COST SOURCE PAGE

SPECIFICATIONS

(IN) (\$/SF)
$4.0 \quad 10.82$
DP 66
FACING PANEL MODULAR UNITS, LIGHT TEXTURE, STANDARD, 4'X10'
4.011 .52
DP 66
FACING PANEL MDDULAR UNITS, MEDIUM TEXTURE, STANDARD, 4'X10'
4.011 .54
DP 66
FACING PANEL MODULAR UNITS, DEEP TEXTURE, STANDARD, $4^{\prime} \times 1^{\prime}$
5.011 .86
DP 66
FACING PANEL MODULAR UNITS, MEDIUM TEXTURE, STANDARD, 5' $\times 14^{\prime}$
5.011 .86
DP 66
FACING PANEL MODULAR UNITS, LIGHT TEXTURE, STANDARD, S'X14'
4.011 .97
DP 66

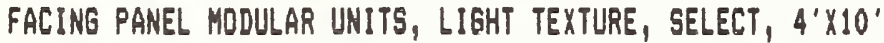
4.512 .05
DP 66
FACING PANEL MDDULAR UNITS, MEDIUM TEXTURE, STANDARD, 4'X14'
4.512 .10
DP $\quad 66$
FACING PANEL MDDULAR UNITS, LIGHT TEXTURE, STANDARD, 4'X14'
5.012 .22
DP $\quad 66$
FACING PANEL MODULAR UNITS, DEEP TEXTURE, STANDARD, $5^{\prime} \times 14^{\prime}$
4.512 .32
DP $\quad 66$
FACING PANEL MODULAR UNITS, DEEP TEXTURE, STANDARD, $4^{\prime} \times 14^{\prime}$
4.012 .62
DP 66
FACING PANEL MODULAR UNITS, MEDIUM TEXTURE, SELECT, 4'X10'
$4.0 \quad 12.67$
DP 66
FACING PANEL MODULAR UNITS, DEEP TEXTURE, SELECT, 4'X10'
4.512 .80
MRR 70
5'X12', TEXTURED FINISH, STICK LIGHT, CUT STONE PANELS
4.512 .90 MRR 70
5'X12', TEXTURED FINISH, RIBBED MEDIUM, CUT STONE PANELS
5.012 .91 DP 66
FACING PANEL MODULAR UNITS, MEDIUM TEXTURE, SELECT, S'XI4'
5.012 .91 DP 66
FACIAG PANEL MODULAR UNITS, LIGHT TEXTURE, SELECT, 5'X14'
4.513 .00
DP 66
4.513 .15 DP 66
FACING PANEL MODULAR UNITS, LIGHT TEXTURE, SELECT, 4'X14'
4.513 .20 MRR 70
FACING PANEL MODULAR UNITS, MEDIUM TEXTURE, SELECT, 4'XI4'
5.013 .34 DP 66
5'X12', TEXTURED FINISH, RIBBED DEEP, CUT STONE PANELS
4.513 .35 DP 66
FACING PANEL MDDULAR UNITS, DEEP TEXTURE, SELECT, 5'X14'
$4.5 \quad 13.40 \quad$ MRR 70
FACING PANEL MODULAR UNITS, DEEP TEXTURE, SELECT, 4'X14'
5.015 .10
5'X12', TEXTURED FINISH, SUGARCUBE, CUT STONE PANELS
5.015 .10
MRR 70
5'X14', TEXTURED FINISH, RIBBED MEDIUM, CUT STONE PANELS
3.015 .15
MRR 70
5'X14', TEXTURED FINISH, STICK LIGHT,CUT STONE PANELS
$5.0 \quad 15.50$
MRR 70
4'X9', SMOOTH FINISH, CUT STONE PANELS
2.016 .25
MRR 70
5'X14', TEXTURED FINISH, RIBBED DEEP, CUT STONE PANELS
4.017 .30
MRR 70
$3^{\prime} \times 5^{\prime}$, SAUN FINISH,CUT STONE PANELS
MRR 70
S'X11', SMDOTH FINISH, CUT STONE PANELS
2.017 .40
MRR 70
$3^{\prime} \times 5^{\prime}$, SMOOTH FINISH, CUT STONE PANELS
4.517 .45 MRR 70
5'X14', TEXTURED FINISH, SUGARCUBE, CUT STONE PANELS 
Table B.11

MARBLE HALLS

ITEM THCK COST SOURCE PAGE

SPECIFICATIONS

(IN) (\$/SF)

$1 \quad 1.25 \quad 15.86$ DP $\quad 67$

$\begin{array}{lllll}2 & 1.25 & 35.91 & \text { DP } & 67\end{array}$

$3 \quad 1.2516 .54$ DP 67

$\begin{array}{lllll}4 & 1.50 & 17.93 \quad \text { DP } & 67\end{array}$

$5 \quad 1.5018 .00 \quad$ DP $\quad 67$

$6 \quad 1.2518 .44$ DP 67

$\begin{array}{lllll}7 & 1.50 & 18.60 & \text { DP } & 67\end{array}$

$8 \quad 1.2519 .06$ DP 67

$9 \quad 1.5020 .50$ DP 67

$10 \quad 1.0020 .95$ BER 57

$11 \quad 1.5021 .15$ DP 67

$120.7524 .00 \quad$ MRR 70

$13 \quad 1.50 \quad 26.59 \quad$ BER 57

$14 \quad 1.5027 .42$ MRR 70

$15 \quad 0.7529 .00 \quad$ MRR 70

$16 \quad 2.2530 .95 \quad$ MRR 70

$\begin{array}{lllll}17 & 2.25 & 32.13 & \text { BER } & 57\end{array}$

$18 \quad 1.50 \quad 32.42$ MRR 70

$19 \quad 2.2535 .95$ MRR 70
FACING PANEL, POLISHED, MELZOTINT

FACING PANEL, POLISHED, SOLAR gRAY

FACINg PANEL, POLISHED, hHITE CHEROKEE gEORgIA

FACING PANEL, POLISHED, MEIZOTINT

FACING PANEL, POLISHED, SOLAR gRAY

FACING PANEL, POLISHED, ETOWAH FLEURI PINK TYPE

FACING PANEL, POLISHED, WHITE CHEROKEE GEORGIA

FACING PANEL, POLISHED, GOLDEN VEIN GEORGIA

FACING PANEL, POLISHED, ETONAH FLEURI PINK TYPE

FACING PAMELS, MEDIAN QUALITY \& COST

FACING PANEL, POLISHED, GOLDEN VEIN GEORGIA

FACING PANEL, UNIFORM COLOR

FACING PANELS, MEDIAN QUALITY \& COST

FACING PANEL, UNIFORM COLOR

FACING PANEL, MULTI-COLOR

FACING PANEL, UNIFORM COLOR

FACING PANELS, MEDIAN QUALITY \& COST

FACING PANEL, MULTI-COLOR

FACING PANEL, MULTI-COLOR 
Table B.12

REPOINTING BRICK WALLS

ITEM COST (\$LF) SOURCE PAEE SPECIFICATIONS

\begin{tabular}{|c|c|c|c|}
\hline$\$ 2.56$ & MRR & 72 & RUNNING BOND, NO STAGING,CUT \& REPOINT,SOFT OLD MORTAR \\
\hline$\$ 2.66$ & MRR & 72 & COMMON BOND,NO STAEING,CUT \& REPOINT,SOFT OLD MORTAR \\
\hline$\$ 2.77$ & MRR & 72 & RUNNING BOND, NO STAGING INCL, REPOINT, MASK\&GROUT METHOD \\
\hline$\$ 2.83$ & MRR & 72 & FLEMISH BOND, NO STAGING, CUT \& REPOINT,SOFT OLD MORTAR \\
\hline$\$ 2.91$ & MRR & 72 & COMMON BOND, NO STAGING INCL, REPOINT, MASK\&GROUT METHOD \\
\hline$\$ 3.04$ & MRR & 72 & FLEMISH BOND, NO STAGING INCL, REPOINT, MASK\&GROUT METHOD \\
\hline$\$ 3.10$ & MRR & 72 & ENGLISH BOND,NO STAGING, CUT \& REPOINT,SOFT OLD MORTAR \\
\hline$\$ 3.16$ & MRR & 72 & RUNNING BOND, NO STAGING,CUT \& REPOINT, HARD MORTAR \\
\hline$\$ 3.25$ & BER & 59 & MEDIAN REPAIRS \\
\hline$\$ 3.28$ & MRR & 72 & COMMON BOND,NO STAGING,CUT \& REPOINT, HARD MORTAR \\
\hline$\$ 3.36$ & MRR & 72 & ENGLISH BOND, NO STAGING INCL, REPOINT, MASK\&GROUT METHOD \\
\hline$\$ 3.60$ & MRR & 72 & FLEMISH BOND, NO STAGING, CUT \& REPOINT, HARD MORTAR \\
\hline$\$ 3.87$ & MRR & 72 & ENGLISH BOND, NO STAGING, CUT \& REPOINT, HARD MORTAR \\
\hline
\end{tabular}


Table B.13

REPOINTING GLOCK WALLS

$\begin{array}{lcccc}\text { ITEM } & \text { COST (\$LF) SOURCE PAGE } & \text { SPECIFICATIONS } \\ 1 & \$ 0.77 & \text { BER } & 59 & \text { SCRAPE \& REPOINT WITH FILL \& GROUT } \\ 2 & \$ 0.88 & \text { BER } & 59 & \text { MEDIAN REPAIRS, } 8 \text { X } 16 \text { IN BLOCK } \\ 3 & \$ 1.73 & \text { MRR } & 72 & \text { SOFT OLD MORTAR, NO STAGING, CUT \& REPOINT } \\ 4 & \$ 1.94 & M R R & 72 & \text { HARD MORTAR,NO STAGING, CUT \& REPOINT }\end{array}$


Table B.14

BALVANIZED BTEEL ROOFING

ITEM BAUEE COST $(\$ / 8 F)$ BQURCE PABE SPECIFICATIONS

\begin{tabular}{|c|c|c|c|c|c|}
\hline 1 & 29 & $\$ 1.37$ & MRR & 119 & CORRUGATED OR RIBBED \\
\hline 2 & 29 & $\$ 1.39$ & DP & 110 & CORR O.IRON INST. STEEL FRAME, UNINS \\
\hline 3 & 26 & $\$ 1.46$ & $D P$ & 110 & CORR O.IRON INST, STEEL FRAME, UNINS \\
\hline 4 & 24 & $\$ 1.56$ & DP & 110 & CORR O.IRON INBT. STEEL FRAME, UNINS \\
\hline 5 & 26 & $\$ 1.58$ & MRR & 119 & CORRUGATED OR RIBBED \\
\hline 6 & 22 & $\$ 1.64$ & $D P$ & 110 & CORR O.IRON INBT, STEEL FRAME, UNINS \\
\hline 7 & 24 & $\$ 1.92$ & MRR & 119 & CORRUGATED OR RIBBED \\
\hline 8 & 22 & $\$ 2.10$ & MRR & 119 & CORRUEATED OR RIBBED \\
\hline 9 & 28 & $\$ 2.21$ & BER & 85 & SHEET METAL, PRESSED PANELS \\
\hline 10 & 26 & $\$ 2.26$ & BER & 83 & PREFORMED BALV METAL, UNINSULATED \\
\hline 11 & 28 & $\$ 2.33$ & BER & 85 & SHEET METAL, STANDING SEAM \\
\hline 12 & 26 & $\$ 2.37$ & BER & 85 & SHEET METAL, STANDING SEAM \\
\hline 13 & 24 & $\$ 2.46$ & BER & 83 & PREFORMED GALV METAL, UNINSULATED \\
\hline 14 & 26 & $\$ 2.49$ & BER & 85 & SHEET METAL, PRESSED PANELS \\
\hline 15 & 24 & $\$ 2.53$ & BER & 85 & SHEET METAL, PRESSED PANELS \\
\hline 16 & 22 & $\$ 2.57$ & BER & 83 & PREFORMED GALV METAL, UNINSULATED \\
\hline 17 & 28 & $\$ 2.65$ & BER & 85 & SHEET METAL, BATTEN SEAM \\
\hline 18 & 22 & $\$ 2.70$ & BER & 85 & SHEET METAL, PRESSED PANELS \\
\hline 19 & 26 & $\$ 2.78$ & BER & 85 & SHEET METAL, BATTEN SEAM \\
\hline 20 & 24 & $\$ 2.81$ & BER & 85 & SHEET METAL, BATTEN SEAM \\
\hline 21 & 20 & $\$ 2.88$ & BER & 83 & PREFORMED GALV METAL, UNINSULATED \\
\hline 22 & 18 & $\$ 3.21$ & BER & 83 & PREFORMED GALV METAL, UNINSULATED \\
\hline 23 & NS & $\$ 4.40$ & $D P$ & 112 & ZINC SHEET METL, STANDING SEAM, 18 DZ \\
\hline 24 & NS & $\$ 4.59$ & DP & 112 & ZINC SHEET METL,STANDING SEAM, $20 \mathrm{OZ}$ \\
\hline 25 & NS & $\$ 4.87$ & DP & 112 & ZINC SHEET METAL, BATTEN SEAM, $180 Z$ \\
\hline
\end{tabular}

$N S=$ NOT SFECIFIED 
Table B.15

COPPER RODFING

\begin{tabular}{|c|c|c|c|c|}
\hline ITEM & SEAM & $\begin{array}{l}\text { WE I GHT } \\
\text { (OZZ) }\end{array}$ & $\begin{array}{l}\text { COST } \\
(\$ / S F)\end{array}$ & \\
\hline
\end{tabular}

\begin{tabular}{|c|c|c|c|c|c|c|c|c|}
\hline 1 & FLAT & 16 & $\$ 4.60$ & MRR & 120 & DVER 10 & SQUARES, 115 & LB/SQUARE \\
\hline 2 & STAN & 16 & $\$ 4.60$ & MRR & 120 & DVER 10 & SQUARES, 125 & LB/SQUARE \\
\hline 3 & STAN & 18 & $\$ 5.00$ & MRR & 120 & OVER 10 & SQUARES, 140 & LB/SQUARE \\
\hline 4 & BATT & 16 & $\$ 5.05$ & MRR & 120 & DVER 10 & SQUARES, 130 & LB/SQUARE \\
\hline 5 & FLAT & 20 & $\$ 5.30$ & MRR & 120 & DVER 10 & SQUARES, 145 & LB/SQUARE \\
\hline 6 & STAN & 20 & $\$ 5.50$ & MRR & 120 & DVER 10 & SQUARES, 150 & LB/SQUARE \\
\hline 7 & BATT & 18 & $\$ 5.55$ & MRR & 120 & DVER 10 & SQUARES, 145 & LB / SQUARE \\
\hline 8 & BATT & 16 & $\$ 5.69$ & DP & 112 & & & \\
\hline 9 & BATT & 20 & $\$ 5.80$ & MRR & 120 & DUER 10 & SQUARES, 160 & LB/SQUARE \\
\hline 10 & FLAT & 16 & $\$ 6.31$ & $D P$ & 112 & & & \\
\hline 11 & FLAT & 16 & $\$ 6.63$ & BER & 84 & & & - \\
\hline 12 & BATT & 20 & $\$ 6.70$ & $D P$ & 112 & & & \\
\hline 13 & STAN & 16 & $\$ 6.85$ & BER & 84 & & & \\
\hline 14 & FLAT & 20 & $\$ 7.00$ & BER & 84 & & & \\
\hline 15 & FLAT & 20 & $\$ 7.23$ & $D P$ & 112 & & & \\
\hline 16 & BATT & 16 & $\$ 7.25$ & BER & 84 & & & \\
\hline 17 & FLAT & 18 & $\$ 7.37$ & BER & 84 & & & \\
\hline 18 & STAN & 18 & $\$ 7.54$ & BER & 84 & & & \\
\hline 19 & STAN & 20 & $\$ 8.23$ & BER & 84 & & & \\
\hline 20 & BATT & 18 & $\$ 8.30$ & BER & 84 & & & \\
\hline 21 & BATT & 20 & $\$ 8.74$ & BER & 84 & & & \\
\hline
\end{tabular}

SEAM TYPES: STAN = STANDING, BATT = BATTEN, FLAT = FLAT. 
Table B.16

GALVANIZED GUTTERS

ITEM SIZE (IN)* COST (\$/LF) SOURCE PAGE

SPECIFICATIONS

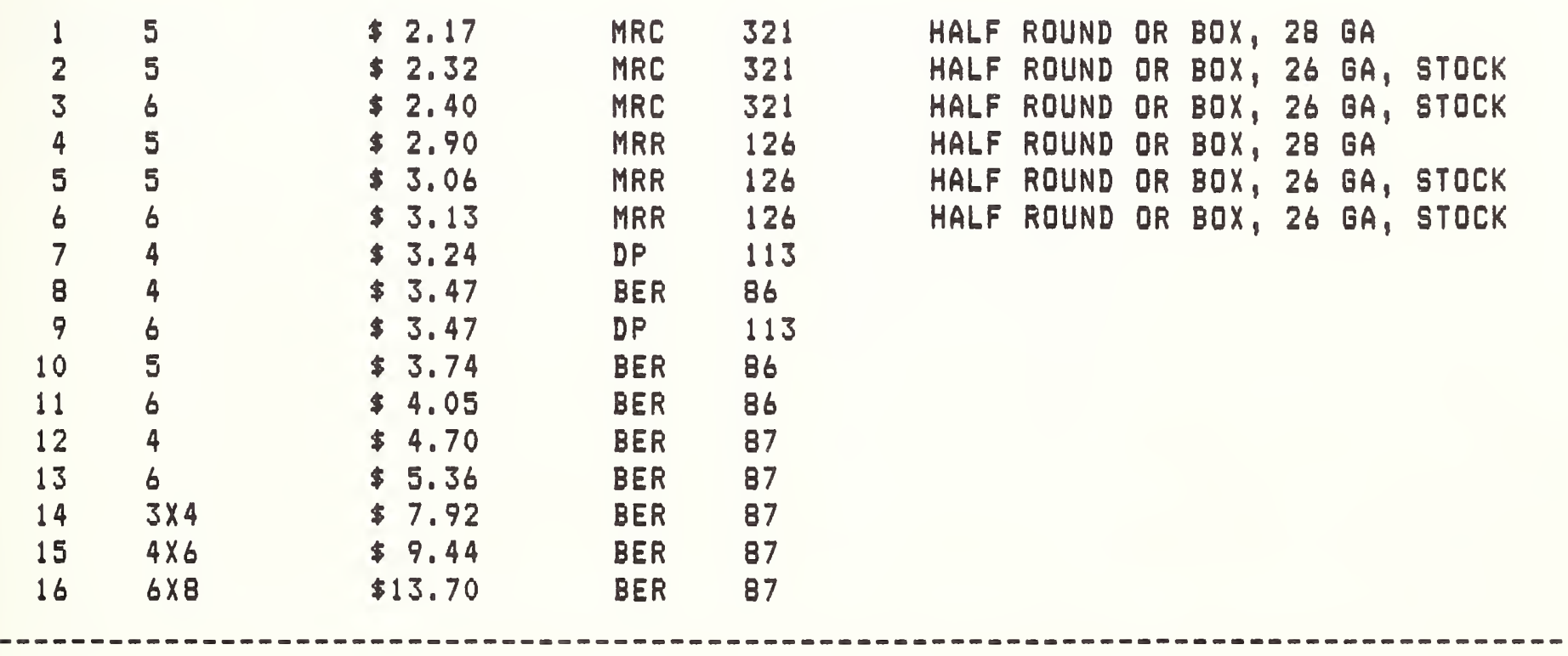

*SIZES WITH ONE DIMENSION SPECIFY THE DIAMETER!

SIZES WITH TWO DIMENSIONS SPECIFY THE HEIGHT AND WIDTH. 
Table B.17

COPPER QUTTERS

ITEM SIZE (IN)* COST (\$LF) SOURCE PAGE SPECIFICATIONS

$\begin{array}{lllllll}1 & 4 & \$ 6.40 & \text { MRR } & 125 & 1602, \text { HALF ROUND, STOCK UNITS } \\ 2 & 5 & \$ 6.70 & \text { MRR } & 125 & 16 \text { OZ, HALF ROUND, STOCK UNITS } \\ 3 & 4 & \$ 7.55 & \text { MRR } & 125 & K \text { TYPE GUTTER, STOCK } \\ 4 & 6 & \$ 7.80 & \text { MRR } & 125 & 1602, \text { HALF ROUND, STOCK UNITS } \\ 5 & 4 & \$ 7.92 & \text { DP } & 113 & 1602 & \\ 6 & 5 & \$ 8.65 & \text { MRR } & 125 & K \text { TYPE GUTTER, STOCK } \\ 7 & 4 & \$ 8.70 & \text { BER } & 87 & \\ 8 & 4 & \$ 8.83 & \text { BER } & 86 & 1802 \\ 9 & 3 \times 4 & \$ 9.65 & \text { BER } & 87 & \\ 10 & 5 & \$ 9.97 & \text { BER } & 86 & 1802 \\ 11 & 6 & \$ 10.18 & \text { DP } & 113 & 1602 \\ 12 & 6 & \$ 10.49 & \text { BER } & 87 & & \\ 13 & 6 & \$ 10.66 & \text { BER } & 86 & 1802 \\ 14 & 4 \times 6 & \$ 11.37 & \text { BER } & 87 & & \\ 15 & 6 \times 8 & \$ 16.67 & \text { BER } & 87 & & \end{array}$

*SIZES WITH ONE DIMENSION SPECIFY THE DIAMETER;

SIZES WITH TWO DIMENSIONS SPECIFY THE HEIGHT AND WIDTH. 
Table B.18

GALVANIZED DOWNSFOUTS ON RESIDENTIAL BUILDINGS

ITEM SIZE (IN)* COST (\$LF) SOURCE PAGE SPECIFICATIONS

$\begin{array}{lllllll}1 & 2 & \$ 1.36 & \text { MRC } & 318 & \text { CORRUGATED, 28 GA } \\ 2 & 3 & \$ 1.36 & \text { MRC } & 318 & \text { CORRUGATED, 28 GA } \\ 3 & 2 \times 3 & \$ 1.38 & \text { MRC } & 318 & \text { PLAIN, 28 GA } \\ 4 & 2 \times 3 & \$ 1.42 & \text { MRC } & 318 & \text { CORRUGATED, 28 GA } \\ 5 & 2 & \$ 1.82 & \text { MRR } & 121 & \text { CORRUGATED, 28 GA } \\ 6 & 3 & \$ 1.82 & \text { MRR } & 121 & \text { CORRUGATED, 28 GA } \\ 7 & 2 \times 3 & \$ 1.85 & \text { MRR } & 121 & \text { PLAIN, 28 GA } \\ 8 & 3 \times 4 & \$ 1.86 & \text { MRC } & 318 & \text { CORRUGATED, 28 GA } \\ 9 & 3 \times 4 & \$ 1.86 & \text { MRC } & 318 & \text { PLAIN, 28 GA } \\ 10 & 2 \times 3 & \$ 1.88 & \text { MRR } & 121 & \text { CORRUGATED, 28 GA } \\ 11 & 2 \times 3 & \$ 2.15 & \text { DP } & 114 & & \\ 12 & 3 \times 4 & \$ 2.37 & \text { DP } & 114 & & \\ 13 & 3 \times 4 & \$ 2.47 & \text { MRR } & 121 & \text { PLAIN, 28 GA } \\ 14 & 3 \times 4 & \$ 2.47 & \text { MRR } & 121 & \text { CORRUGATED, 28 GA } \\ 15 & 2 \times 3 & \$ 3.97 & \text { BER } & 86 & & \\ 16 & 3 \times 4 & \$ 4.21 & \text { BER } & 86 & & \\ 17 & 3 & \$ 5.73 & \text { DP } & 114 & & \end{array}$

*SIZES WITH ONE DIMENSION SPECIFY THE DIAMETER;

SIZES WITH TWO DIMENSIONS SPECIFY THE HEIGHT AND WIDTH. 
Table B.19

GALVANIZED DOWNSPOUTS ON COMMERCIAL BUILDINGS

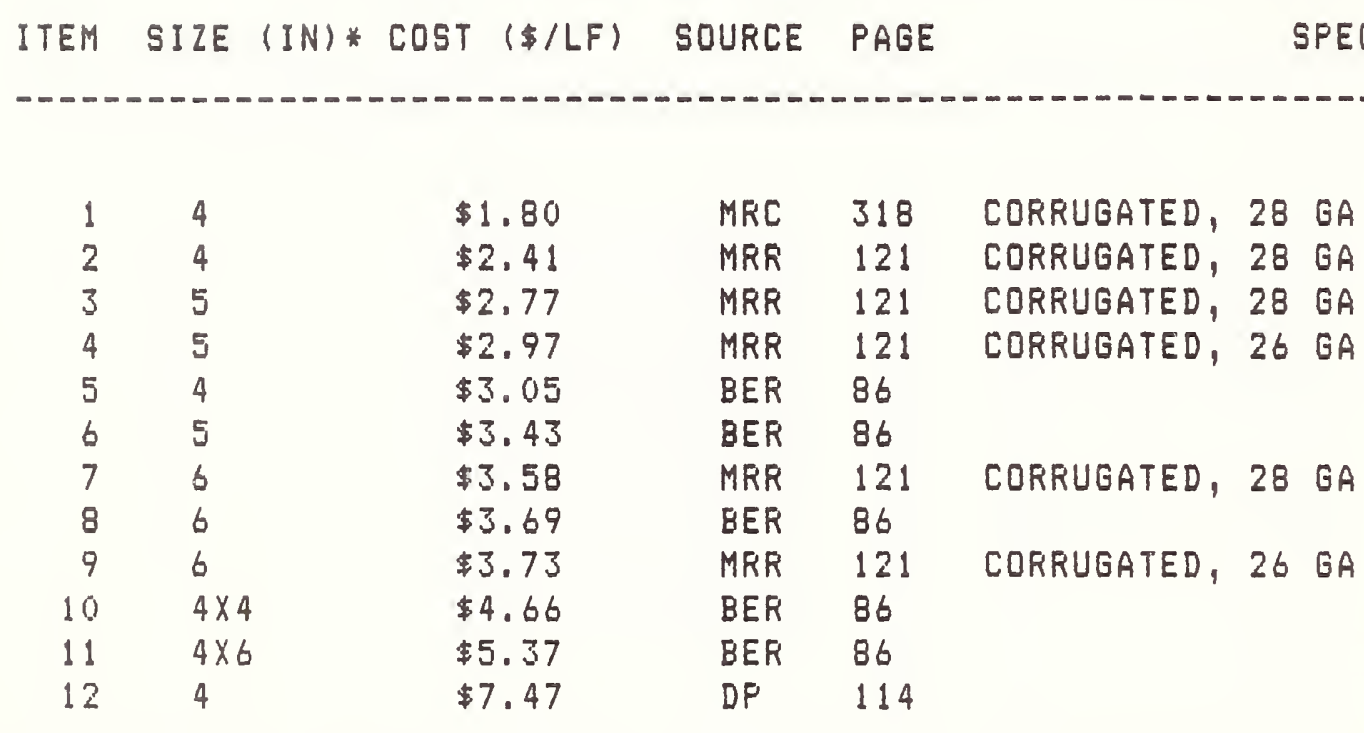

* SIZES WITH ONE DIMENSION SPECIFY THE DIAMETER;

SIZES WITH TWO DIMENSIONS SPECIFY THE HEIGHT AND WIDTH. 
Table B. 20

COPPER DOWNSPQUTS ON RESIDENTIAL BUILDINGS

ITEM SIZE (IN)* COST (\$LF) SOURCE PAGE SPECIFICATIONS

$\begin{array}{llllll}1 & 2 & \$ 5.45 & \text { MRR } & 120 & 1602, \text { STOCK } \\ 2 & 3 & \$ 6.12 & \text { DP } & 114 & 1602 \\ 3 & 3 & \$ 6.60 & \text { MRR } & 120 & 160 Z, \text { STOCK } \\ 4 & 2 \times 3 & \$ 6.95 & \text { MRR } & 121 & \text { CORRUGATED, STOCK } \\ 5 & 2 \times 3 & \$ 7.10 & \text { MRR } & 121 & \text { PLAIN, STOCK } \\ 6 & 2 \times 3 & \$ 8.05 & \text { DP } & 114 & 1602 \\ 7 & 2 \times 3 & \$ 8.16 & \text { BER } & 86 & \\ 8 & 3 \times 4 & \$ 8.75 & \text { MRR } & 121 & \text { PLAIN, STOCK } \\ 9 & 3 \times 4 & \$ 9.13 & \text { BER } & 86 & \\ 10 & 3 \times 4 & \$ 9.15 & \text { MRR } & 121 & \text { CORRUGATED, STOCK } \\ 11 & 3 \times 4 & \$ 9.40 & \text { DP } & 114 & 160 Z\end{array}$

*SIZES WITH ONE DIMENSION SPECIFY THE DIAMETER;

SIZES WITH TWO DIMENSIONS SPECIFY THE HEIGHT AND WIDTH. 
Table B.2I

COFPER DOWNSPOUTS ON COMMERCIAL BUILDINGS

ITEM SIZE (IN)* COST (\$LF) SOURCE PAGE SPECIFICATIONS

$\begin{array}{lllllll}1 & 4 & \$ 8.12 & \text { DP } & 114 & 160 z \\ 2 & 4 & \$ 8.28 & \text { BER } & 86 & 180 z \\ 3 & 4 & \$ 8.75 & \text { MRR } & 120 & 160 z, \text { STOCK } \\ 4 & 5 & \$ 9.01 & \text { BER } & 86 & 180 z \\ 5 & 5 & \$ 9.35 & \text { MRR } & 120 & 160 z, \text { STOCK } \\ 6 & 6 & 10.01 & \text { BER } & 86 & 180 z \\ 7 & 4 \times 4 & 10.10 & \text { BER } & 86 & & \\ 8 & 4 \times 6 & 12.24 & \text { BER } & 86 & & \end{array}$

*SIZES WITH ONE DIMENSION SPECIFY THE DIAMETER;

SIZES WITH TWO DIMENSIONS SPECIFY THE HEIGHT AND WIDTH. 
Table B.22

GALVANIZED STEEL CHAIN LINK FENCING

ITEM HGHT GA COST SOURCE PAGE

SPECIFICATIONS

(FT) (\$/SF)

4.0 11 1.31 MRR 45 RESIDENTIAL, $15 / 8 "$ LINE POST $10^{\circ}$ O.C., I 3/8" TOP RAIL, GATE 3' WIDE, 1 3/8" FRAME

6.0 NS 1.39 BOE R77 RESIDENTIAL. WALK-IN GATES.

3.011 1.41 MRR 45 RESIDENTIAL, I 5/8" LINE POST \& 10' O.C., I 3/8" TOP RAIL, GATE 3' WIDE, I 3/8" FRAME

5.0 NS 1.43 BOE R77 RESIDENTIAL. HALK-IN GATES.

$6.011 \quad 1.53$ BER 30 STD RES. ROUND POST, GATE FRAME BRACE, RAIL, STRETCHER BAR, TRUSS ROD\&TENSION WIRE, 2X2MESH, GATE HARDWARE

$7.011 \quad 1.54$ BER 3O STD RES. ROUND POST, GATE FRAME BRACE, RAIL, STRETCHER BAR, TRUSS ROD\&TENSION WIRE, 2X2MESH, GATE HARDHARE

4.0 NS 1.57 BOE R77 RESIDENTIAL. HALK-IN GATES.

3.0 NS 1.69 BOE R77 RESIDENTIAL. HALK-IN GATES.

$5.011 \quad 1.71$ BER 30 STD RES. ROUND POST, GATE FRAME BRACE, RAIL, STRETCHER BAR, TRUSS ROD\&TENSION WIRE, 2X2MESH, GATE HARDWARE

12.091 .73 BER 29 STD IND.ROUND PQST, GATE FRAME BRACE, RAIL, STRETCHER BAR, TRUSS ROD\&TENSION WIRE, 2X2MESH, GATE HARDHARE

10.091 .76 BER 29 STD IND. ROUND POST, GATE FRAIE BRACE, RAIL, STRETCHER BAR, TRUSS ROD\&TENSION WIRE, 2X2MESH, GATE HARDHARE

8.091 .83 BER 29 STD IND.ROUND POST, GATE FRAME BRACE, RAIL, STRETCHER BAR, TRLSS RODRTENSION WIRE, 2X2MESH, GATE HARDHARE

6.091 .84 BER 29 STD IND. ROUND POST, GATE FRAME BRACE, RAIL, STRETCHER BAR, TRUSS ROD\&TENSION WIRE, 2X2MESH, GATE HARDHARE

7.091 .85 BER 29 STD IND.ROUND POST, GATE FRAME BRACE, RAIL, STRETCHER BAR, TRUSS ROD\&TENSION WIRE, 2X2MESH, GATE HARDMARE

4.091 .88 DP 34 RESIDENTIAL. INCLUDES EXCAVATION AND CONCRETE FOR POSTS INSTALLED IN EARTH. 3' WIDE GATE.

6.091 .88 DP 34 INCLUDES EXCAVATION AND CONCRETE FOR POSTS INSTALLED IN EARTH. $2^{\circ}$ POSTS $10^{\circ} 0.0^{\circ}$.

$8.0 \quad 9 \quad 1.88$ BOE 518

4.0111 .89 BER 30 STD RES. ROUND POST, GATE FRAME BRACE, RAIL, STRETCHER BAR, TRUSS ROD\&TENSION WIRE, 2X2MESH, GATE HARDHARE

3.5112 .08 BER 30 STD RES. ROUND POST, GATE FRAME BRACE, RAIL, STRETCHER BAR, TRUSS ROD\&TENSION HIRE, 2X2MESH, GATE HARDWARE

5.092 .08 BER 29 STD IND.ROUND POST, GATE FRAME BRACE, RAIL, STRETCHER BAR, TRLSS ROD\&TENSION WIRE, 2X2MESH, GATE HARDHARE

3.092 .08 DP 34 RESIDENTIAL. INCLUDES EXCAVATION AND CONCRETE FOR POSTS INSTALLED IN EARTH. 3' WIDE GATE.

4.092 .29 BER 29 STD IND.ROUND POST, GATE FRAME BRACE, RAIL, STRETCHER BAR, TRUSS ROD\&TENSION WIRE, 2X2HESH, GATE HARDWARE

3.0112 .38 BER 30 STD RES. ROUND POST, GATE FRAME BRACE, RAIL, STRETCHER BAR, TRUSS ROD\&TENSION WIRE, 2X2MESH, GATE HARDWARE

3.592 .54 BER 29 STD IND. ROUND POST, GATE FRAME BRACE, RAIL, STRETCHER BAR, TRUSS RODRTENSION WIRE, 2X2MESH, GATE HARDHARE

3.092 .90 BER 29 STD IND. ROUND POST, GATE FRAME BRACE, RAIL, STRETCHER BAR, TFUSS ROD\&TENSION HIRE, 2X2MESH, GATE HARDHARE 
Table B.23

GALVAMIZED STEEL MESH FENCING

ITEM HGHT GA COST SOURCE PAGE

SPECIFICATIONS

(FT)

(\$/SF)

15.0120 .50 DP $352^{\prime \prime X} 4 "$ MESH. INCLUDES EXCAVATION AND CONCRETE FOR POSTS INSTALLED IN EARTH.

$25.0 \quad 140.51$ DP 35 1"X2" MESH. INCLUDES EXCAVATION AND CONCRETE FOR POSTS INSTALLED IN EARTH.

$3 \quad 3.0 \quad 120.58$ DP $352^{\circ} \times 4^{\prime \prime}$ MESH. INCLUDES EXCAVATION AND CONCRETE FOR POSTS INSTALLED IN EARTH.

$43.0 \quad 140.69$ DP $351^{\circ} \times 2^{\prime \prime}$ MESH. INCLUDES EXCAVATION AND CONCRETE FOR POSTS INSTALLED IN EARTH.

$5 \quad 5.0 \quad 14 \quad 0.71 \quad$ BER $30 \quad 1^{\text {"XX }} 2^{\prime \prime}$ MESH, 6' O.C. POSTS

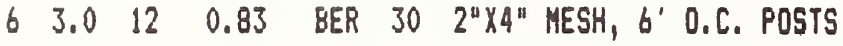

$73.0 \quad 14 \quad 0.99$ BER $30 \quad 1$ "X2" MESH, b' O.C. POSTS

$\begin{array}{lllllll}8 & 3.0 & 12 & 1.07 & \text { BER } 30 & 1 \text { "X2" MESH, 6' O.C. POSTS }\end{array}$ 
Table B.24

RESIDENTIAL GALVANIZED STEEL CHAIN LIHK GATES

IIEM HGHT WDTH GA COST SOURCE PAGE

SPECIFICATIONS

(FT) (FT) (\$/SF)

16.03112 .95 BER 30 RES, ROUND POST, GATE FRAME BRACE, RAIL, STRETCHER BAR, TRUSS RODRTENSION WIRE, 2X2MESH, HARDHARE

27.03 II 3.02 BER 30 RES, ROUND POST, GATE FRAME BRACE, RAIL, STRETCHER BAR, TRUSS ROD\&TENSION WIRE, 2X2MESH, HARDHARE

$35.03 \quad 113.21$ BER 30 RES, ROUND POST, GATE FRAME BRACE, RAIL, STRETCHER BAR, TRUSS ROD\&TENSION WIRE, 2X2MESH, HARDHARE

44.03113 .41 MRR 45 RES, I 5/8' LINE POST $10^{\circ}$ O.C., I 3/8' TOP RAIL, I 3/8' FRAME

$5 \quad 4.03113 .47$ BER 30 RES, ROUND POST, GATE FRAME BRACE, RAIL, STRETCHER BAR, TRUSS ROD\&TENSION WIRE, 2X2MESH, HARDHARE

$6 \quad 3.53113 .77$ BER 3O RES, ROUND POST, GATE FRAME BRACE, RAIL, STRETCHER BAR, TRUSS ROD\&TEMSION WIRE, 2X2MESH, HARDHARE

73.03114 .22 MRR 45 RES, $15 / 8^{\prime}$ LINE POST $10^{\prime}$ O.C., I 3/8' TOP RAIL, I 3/8' FRAME

83.03114 .25 BER 30 RES, ROUND POST, GATE FRAME BRACE, RAIL, STRETCHER BAR, TRUSS ROD\&TENSION WIRE, 2X2MESH, HARDWARE

94.03 NS 6.99 BOE R77 RES

$10 \quad 3.0 \quad 3$ NS 7.98 BOE R77 RES

114.0394 .63 DP 34 RES, INCLUDES EXCAVATION AND CONCRETE FOR POSTS INSTALLED IN EARTH

123.03910 .26 DP 34 RES, INCLUDES EXCAVATION AND CONCRETE FOR POSTS INSTALLED IN EARTH

NS = NOT SPECIFIED 
Table B.25

COMHERCIAL GALUANIZED STEEL CHAIN LINK BATES

ITEM HGHT WDTH GA COST SOURCE PAGE

(FT) (FT)

(\$/SF)

SPECIFICATIONS

16.01091 .07 BER 29 IMD, ROUND POST, GATE FRAME BRACE, RAIL, STRETCHER BAR, TRUSS RODETEHSION WIRE, 2X2MESH, HARDHARE

27.01091 .09 BER 29 IND, ROUND POST, GATE FRAME BRACE, RAIL, STRETCHER BAR, TRUSS ROD\&TENSION WIRE, 2X2MESH, HARDHARE

$312.0 \quad 1091.10$ BER 29 IND, ROUND POST, GATE FRAME BRACE, RAIL, STRETCHER BAR, TRUSS RODLTENSION WIRE, 2X2MESH, HARDWARE

$410.0 \quad 1091.10$ BER 29 IND, ROUND POST, GATE FRAME BRACE, RAIL, STRETCHER BAR, TRUSS RODLTENSION WIRE, 2X 2MESH, HARDHARE

$58.0 \quad 1091.11$ BER 29 IND, ROUND POST, GATE FRAME BRACE, RAIL, STRETCHER BAR, TRUSS ROD\&TENSION WIRE, 2X2MESH, HARDWARE

65.0 10 91.17 BER 29 IND, ROUND POST, GATE FRAME BRACE, RAIL, STRETCHER BAR, TRUSS RODLTENSION WIRE, 2X2MESH, HARDHARE

$74.0 \quad 1091.27$ BEA 29 IND, ROUND POST, GATE FRAME BRACE, RAIL, STRETCHER BAR, TRUSS ROD\&TENSION WIRE, 2X2MESH, HARDHARE

83.51091 .38 BER 29 IND, ROUND POST, GATE FRAME BRACE, RAIL, STRETCHER BAR, TRUSS ROD\&TENSION WIRE, 2X2MESH, HARDHARE

93.01091 .56 BER 29 IND, ROUND POST, GATE FRAME BRACE, RAIL, STRETCHER BAR, TRUSS ROD\&TENSION HIRE, 2X2MESH, HARDHARE 
APPENDIX C: Adjusting for Local Variations in Costs

Each cost estimate given in the tables of appendix $B$ represents average construction costs for the United States. Because costs vary from place to place, however, a method is needed for adjusting the cost estimates to take local cost variations into account. This appendix presents and illustrates such a method based on Means. 1

The method consists of four steps:

Step 1: Find the cost estimate in appendix B.

Step 2: Find the construction division for the MR\&R activity in table C.1.

Step 3: Find the cost index for the relevant city and construction division in table C.2.

Step 4: Use the index from step 3 to adjust the cost estimate.

As an example, suppose one wants to convert a U.S. average cost estimate for installing galvanized steel siding to the equivalent cost in New Haven, Connecticut.

Step 1: Find the relevant cost estinate.

Table B.7, 1tem 11, reports the cost of installing 20 gauge corrugated steel siding as $\$ 2.62 / \mathrm{SF} .2$ If some other kind of siding were to be installed, a different cost estimate would be used.

Step 2: Determine the construction division of the MR\&R activity.

Table C.1 assigns each of 24 MR\&R activities to a particular construction division. The division for galvanized steel siding (walls) is Moisture Protection.

Step 3: Find the cost index for the relevant city and construction division.

Table C.2 gives the cost indices for 156 U.S. cities for four construction divisions: Masonry, Metals, Molsture Protection, and Painting. (A Weighted Average, which includes construction divisions not considered in this report, is also provided. It may be useful if a particular MR\&R activity does not fall into one of the four divisions given here.) The index for Moisture Protection in New Haven, Connecticut is 89.7 .

1Means, Building Construction Cost Data 1984, pp. 323-331.

2 This cost estimate is from MEANS REP \& REM, p. 119. 
Step 4: Adjust the cost estimate.

The cost index states the average cost of work in a certain construction division in a given city as a percent of the average cost for the United States as a whole. Thus, to convert a U.S. average cost estimate from appendix $B$ to a cost estimate for a particular city, multiply the U.S. cost by the index obtained in step 3 and divide by 100:

$$
\text { City Cost }=\text { U.S. cost } \mathrm{x} \text { index/100. }
$$

In our example, the cost of installing the 20 gauge corrugated steel siding in New Haven is $\$ 2.35 /$ SF ( $=\$ 2.62 \times 89.7 / 100)$. 
Table C.1 Construction Divisions for Building Components and MR\&R Activity Groups

\begin{tabular}{lll}
\hline Building & MR\&R Activity & Construction \\
Component & Group & Division
\end{tabular}

(1)

(2)

(3)

Walls

Painting Wood

Painting Masonry

Painting Concrete

Painting Stucco

Painting Metal

Galvanized Steel

Indiana Limestone

Alabama Limestone

other Limestone

Marble

Repointing Brick Mortar

Repointing Block Mortar

Roof s

Gutters

Down-

spouts

Fences
Galvanized Steel

Copper

Galvanized Steel

Copper

Galvanized Residential

Galvanized Commercial

Copper Residential

Copper Commercial

Galvanized Link Fencing

Galvanized Mesh Fencing

Galvanized Gates Residential

Galvanized Gates Commercial
Painting

Painting

Painting

Painting

Painting

Moisture Protection

Masonry

Masonry

Masonry

Masonry

Masonry

Masonry

Moisture Protection

Moisture Protection

Moisture Protection Moisture Protection

Moisture Protection Moisture Protection Moisture Protection Moisture Protection

Metals

Metals

Metals

Metals

Source: MEANS REP \& REM, pp. xxii-xxili and 383. 
Table C.2 Geographic Adjustment Factors Used to Convert U.S. Average Cost Estimates to Their Local Equivalent Values for 156 Cities, by Type of Construction Activity

Construction Activity

\begin{tabular}{|c|c|c|c|c|c|}
\hline State/City & Painting & Masonry & $\begin{array}{l}\text { Moisture } \\
\text { Protection }\end{array}$ & Metals & $\begin{array}{l}\text { Weight } \\
\text { Averag }\end{array}$ \\
\hline \multicolumn{6}{|l|}{ Alabama } \\
\hline Birmingham & 87.7 & 75.6 & 81.6 & 90.8 & 84.6 \\
\hline Huntsville & 85.3 & 80.9 & 87.0 & 93.4 & 88.2 \\
\hline Mobile & 89.9 & 83.4 & 85.5 & 89.8 & 90.3 \\
\hline Montgomery & 85.8 & 75.4 & 84.2 & 90.0 & 85.5 \\
\hline \multicolumn{6}{|l|}{ Alaska } \\
\hline Anchorage & 142.7 & 149.9 & 117.1 & 121.8 & 134.4 \\
\hline \multicolumn{6}{|l|}{ Arizona } \\
\hline Phoen1x & 93.1 & 97.8 & 93.0 & 97.7 & 97.7 \\
\hline Tucson & 94.8 & 93.7 & 103.0 & 94.5 & 97.3 \\
\hline \multicolumn{6}{|l|}{ Arkansas } \\
\hline Fort Smith & 83.5 & 80.2 & 81.2 & 95.5 & 86.6 \\
\hline Little Rock & 86.2 & 80.7 & 82.6 & 97.6 & 88.7 \\
\hline \multicolumn{6}{|l|}{ California } \\
\hline Anaheim & 122.6 & 122.6 & 114.9 & 106.0 & 112.1 \\
\hline Bakersfield & 117.3 & 114.0 & 95.7 & 102.2 & 107.0 \\
\hline Fresno & 119.7 & 119.3 & 108.6 & 102.8 & 111.7 \\
\hline Los Angeles & 119.9 & 119.4 & 114.3 & 110.0 & 111.2 \\
\hline Oxnard & 117.3 & 119.5 & 102.1 & 109.9 & 112.6 \\
\hline Riverside & 118.8 & 119.3 & 99.1 & 105.9 & 110.3 \\
\hline Sacramento & 125.8 & 124.0 & 98.5 & 116.0 & 115.0 \\
\hline San Diego & 126.0 & 117.1 & 104.3 & 104.1 & 110.2 \\
\hline San Francisco & 138.7 & 134.3 & 101.4 & 111.4 & 122.5 \\
\hline Santa Barbara & 122.0 & 120.9 & 99.9 & 105.0 & 113.0 \\
\hline Stockton & 123.4 & 115.9 & 98.5 & 102.1 & 112.3 \\
\hline Vallejo & 130.4 & 128.3 & 100.2 & 101.8 & 115.8 \\
\hline \multicolumn{6}{|l|}{ Colorado } \\
\hline Colorado Springs & 90.2 & 99.1 & 88.4 & 95.0 & 96.1 \\
\hline Denver & 107.8 & 106.5 & 103.0 & 97.2 & 101.6 \\
\hline \multicolumn{6}{|l|}{ Connecticut } \\
\hline Bridgeport & 98.0 & 94.8 & 97.9 & 92.6 & 98.0 \\
\hline Hartford & 104.8 & 93.7 & 99.1 & 93.8 & 98.1 \\
\hline New Haven & 98.5 & 100.3 & 89.7 & 88.4 & 97.2 \\
\hline Stamford & 99.2 & 97.8 & 89.3 & 89.0 & 97.9 \\
\hline Waterbury & 94.8 & 96.6 & 89.1 & 89.7 & 95.9 \\
\hline \multicolumn{6}{|l|}{ Delaware } \\
\hline Wilmington & 87.1 & 97.0 & 91.2 & 94.3 & 99.4 \\
\hline \multicolumn{6}{|l|}{ D.C. } \\
\hline Washington & 103.3 & 93.4 & 100.2 & 98.3 & 95.4 \\
\hline
\end{tabular}


Table C.2 Geographic Adfustment Factors Used to Convert U.S. Average Cost Estimates to Their Local Equivalent Values for 156 Clt1es, by Type of Construction Activity (Continued)

Construction Activity

\begin{tabular}{|c|c|c|c|c|c|}
\hline State/C1ty & Painting & Masonry & $\begin{array}{l}\text { Molsture } \\
\text { Protection }\end{array}$ & Metals & $\begin{array}{l}\text { Welghted } \\
\text { Average }\end{array}$ \\
\hline \multicolumn{6}{|l|}{ Florida } \\
\hline Ft. Lauderdale & 87.2 & 88.5 & 85.8 & 87.9 & 90.9 \\
\hline Jacksonville & 83.4 & 75.5 & 84.4 & 90.9 & 87.9 \\
\hline M1am1 & 90.5 & 85.1 & 86.2 & 89.1 & 91.9 \\
\hline Orlando & 81.6 & 71.4 & 81.3 & 85.6 & 85.3 \\
\hline Tampa & 86.3 & 85.2 & 95.8 & 97.5 & 93.0 \\
\hline \multicolumn{6}{|l|}{ Georgla } \\
\hline Atlanta & 94.9 & 83.3 & 88.1 & 100.0 & 90.3 \\
\hline Columbus & 78.6 & 61.2 & 85.1 & 89.1 & 83.1 \\
\hline Macon & 86.4 & 73.5 & 86.1 & 88.4 & 86.1 \\
\hline Savannah & 82.7 & 77.1 & 86.2 & 95.5 & 87.7 \\
\hline \multicolumn{6}{|l|}{ Hawa11 } \\
\hline Honolulu & 112.9 & 107.0 & 105.1 & 106.0 & 109.1 \\
\hline \multicolumn{6}{|l|}{ Idaho } \\
\hline Boise & 95.9 & 94.8 & 102.0 & 94.0 & 95.7 \\
\hline \multicolumn{6}{|l|}{ Illinois } \\
\hline Chicago & 93.4 & 99.1 & 101.4 & 92.3 & 97.7 \\
\hline Peoria & 102.4 & 100.6 & 94.0 & 94.0 & 97.9 \\
\hline Rockford & 101.3 & 100.3 & 104.5 & 105.2 & 101.2 \\
\hline Springfield & 98.7 & 99.0 & 98.1 & 94.7 & 98.4 \\
\hline \multicolumn{6}{|l|}{ Indiana } \\
\hline Evansville & 92.9 & 97.6 & 90.4 & 94.4 & 97.6 \\
\hline Fort Wayne & 95.2 & 90.0 & 95.1 & 98.4 & 94.7 \\
\hline Gary & 107.9 & 105.1 & 95.6 & 97.1 & 103.4 \\
\hline Indianapolis & 88.4 & 94.6 & 106.0 & 99.9 & 97.5 \\
\hline South Bend & 97.4 & 96.4 & 92.1 & 101.0 & 98.5 \\
\hline Terre Haute & 99.5 & 94.6 & 92.3 & 93.2 & 96.0 \\
\hline \multicolumn{6}{|l|}{ Iowa } \\
\hline Davenport & 98.7 & 100.0 & 90.1 & 92.7 & 98.9 \\
\hline Des Moines & 92.6 & 91.2 & 87.9 & 89.6 & 94.4 \\
\hline \multicolumn{6}{|l|}{ Kansas } \\
\hline Topeka & 94.1 & 86.6 & 92.8 & 100.1 & 92.7 \\
\hline Wichita & 87.1 & 83.6 & 91.1 & 96.0 & 90.8 \\
\hline \multicolumn{6}{|l|}{ Kentucky } \\
\hline Lexington & 91.0 & 89.1 & 86.0 & 88.5 & 93.7 \\
\hline Louisville & 81.7 & 90.6 & 87.1 & 85.8 & 95.0 \\
\hline
\end{tabular}


Table C.2 Geographic Adjustment Factors Used to Convert U.S. Average Cost Est1mates to Their Local Equivalent Values for 156 Cities, by Type of Construction Activity (continued)

Construction Activity

\begin{tabular}{|c|c|c|c|c|c|}
\hline State/City & Painting & Masonry & $\begin{array}{l}\text { Molsture } \\
\text { Protection }\end{array}$ & Metals & $\begin{array}{l}\text { We1ghte } \\
\text { Average }\end{array}$ \\
\hline \multicolumn{6}{|l|}{ Louisiana } \\
\hline Baton Rouge & 78.6 & 95.4 & 98.2 & 99.0 & 93.3 \\
\hline New Orleans & 91.0 & 87.5 & 90.7 & 96.7 & 92.6 \\
\hline Shreveport & 79.2 & 86.5 & 84.4 & 90.5 & 89.6 \\
\hline \multicolumn{6}{|l|}{ Maine } \\
\hline Lewiston & 80.7 & 81.0 & 84.6 & 91.6 & 88.5 \\
\hline Portland & 85.3 & 80.4 & 83.5 & 100.3 & 89.1 \\
\hline \multicolumn{6}{|l|}{ Maryland } \\
\hline Baltimore & 87.4 & 85.8 & 89.6 & 95.5 & 93.1 \\
\hline \multicolumn{6}{|l|}{ Massachusetts } \\
\hline Boston & 100.1 & 104.0 & 116.1 & 108.2 & 104.8 \\
\hline Lawrence & 101.6 & 100.1 & 98.6 & 97.8 & 100.3 \\
\hline Lowe 11 & 102.8 & 103.0 & 99.3 & 95.5 & 100.6 \\
\hline Springfield & 98.5 & 94.7 & 95.9 & 96.5 & 96.5 \\
\hline Worcester & 100.1 & 97.6 & 99.1 & 97.1 & 99.2 \\
\hline \multicolumn{6}{|l|}{ Michigan } \\
\hline Ann Arbor & 109.7 & 102.3 & 96.3 & 98.5 & 102.5 \\
\hline Detroit & 108.5 & 101.4 & 105.4 & 101.6 & 102.9 \\
\hline Flint & 92.0 & 102.2 & 90.4 & 97.2 & 98.8 \\
\hline Grand Rapids & 92.8 & 92.4 & 105.2 & 100.6 & 95.5 \\
\hline Kalamazoo & 98.0 & 94.5 & 90.6 & 99.3 & 96.1 \\
\hline Lansing & 103.1 & 102.1 & 108.8 & 108.6 & 102.0 \\
\hline Saginaw & 103.8 & 99.2 & 95.6 & 103.0 & 99.4 \\
\hline \multicolumn{6}{|l|}{ Minnesota } \\
\hline Duluth & 96.9 & 97.6 & 93.5 & 101.7 & 97.0 \\
\hline Minneapolis & 102.1 & 100.8 & 98.3 & 94.5 & 100.1 \\
\hline \multicolumn{6}{|l|}{ Mississippi } \\
\hline Jackson & 82.8 & 80.7 & 82.0 & 84.2 & 86.3 \\
\hline \multicolumn{6}{|l|}{ Missouri } \\
\hline Kansas City & 98.1 & 95.9 & 96.4 & 102.4 & 98.9 \\
\hline St. Louis & 95.7 & 96.8 & 97.3 & 99.5 & 97.8 \\
\hline \multicolumn{6}{|l|}{ Montana } \\
\hline Billings & 87.9 & 92.6 & 97.0 & 95.3 & 95.5 \\
\hline Great Falls & 93.8 & 91.8 & 97.9 & 89.5 & 94.7 \\
\hline \multicolumn{6}{|l|}{ Nebraska } \\
\hline Lincoln & 87.1 & 86.0 & 86.7 & 86.4 & 91.4 \\
\hline Omaha & 90.1 & 92.2 & 100.7 & 103.4 & 96.0 \\
\hline
\end{tabular}


Table C.2 Geographic Adjustment Factors Used to Convert U.S. Average Cost Estimates to Their Local Equivalent Values for 156 Cities, by Type of Construction Activity (continued)

Construction Activity

\begin{tabular}{|c|c|c|c|c|c|}
\hline State/City & Painting & Masonry & $\begin{array}{l}\text { Moisture } \\
\text { Protection }\end{array}$ & Metals & $\begin{array}{l}\text { Weight } \\
\text { Average }\end{array}$ \\
\hline \multicolumn{6}{|l|}{ Nevada } \\
\hline Las Vegas & 114.3 & 113.7 & 97.3 & 111.6 & 107.9 \\
\hline Reno & 118.7 & 118.4 & 107.2 & 103.8 & 109.2 \\
\hline \multicolumn{6}{|l|}{ New Hampshire } \\
\hline Manchester & 92.5 & 87.1 & 91.8 & 95.0 & 91.7 \\
\hline Nashua & 89.6 & 87.8 & 99.2 & 88.0 & 91.9 \\
\hline \multicolumn{6}{|l|}{ New Jersey } \\
\hline Jersey City & 97.9 & 103.6 & 113.3 & 102.0 & 103.2 \\
\hline Newark & 102.0 & 105.0 & 106.4 & 99.8 & 102.7 \\
\hline Paterson & 102.5 & 104.4 & 111.0 & 98.6 & 103.0 \\
\hline Trenton & 103.6 & 100.0 & 101.6 & 99.1 & 100.1 \\
\hline \multicolumn{6}{|l|}{ New Mexico } \\
\hline Albuquerque & 90.1 & 82.1 & 93.0 & 100.1 & 93.8 \\
\hline \multicolumn{6}{|l|}{ New York } \\
\hline Al bany & 95.5 & 89.7 & 101.3 & 95.3 & 93.7 \\
\hline Binghamton & 89.7 & 85.6 & 95.6 & 95.5 & 90.8 \\
\hline Buffalo & 106.1 & 107.7 & 104.4 & 108.0 & 105.2 \\
\hline New York & 103.8 & 116.8 & 104.5 & 110.6 & 111.8 \\
\hline Rochester & 96.8 & 98.1 & 106.4 & 99.9 & 99.1 \\
\hline Syracuse & 95.1 & 94.2 & 95.7 & 98.2 & 95.6 \\
\hline Utica & 96.1 & 86.6 & 94.5 & 99.6 & 94.1 \\
\hline Yonkers & 112.1 & 112.9 & 109.3 & 106.5 & 108.2 \\
\hline \multicolumn{6}{|l|}{ North Carolina } \\
\hline Charlotte & 72.3 & 71.4 & 81.3 & 92.4 & 83.3 \\
\hline Greensboro & 71.7 & 74.6 & 80.9 & 86.5 & 82.5 \\
\hline Ralefgh & 71.2 & 70.8 & 80.8 & 86.9 & 82.8 \\
\hline \multicolumn{6}{|l|}{ Ohio } \\
\hline Akron & 106.0 & 99.7 & 101.9 & 101.8 & 101.1 \\
\hline Canton & 96.3 & 98.8 & 101.0 & 98.8 & 98.1 \\
\hline Cincinnati & 94.6 & 94.6 & 101.8 & 97.0 & 98.5 \\
\hline Cleveland & 114.5 & 111.8 & 107.4 & 104.6 & 106.8 \\
\hline Columbus & 101.1 & 94.5 & 96.2 & 99.7 & 97.8 \\
\hline Dayton & 99.1 & 93.2 & 101.0 & 99.8 & 99.2 \\
\hline Lorain & 117.7 & 105.6 & 103.7 & 101.9 & 103.0 \\
\hline Toledo & 109.9 & 107.3 & 97.9 & 101.6 & 105.1 \\
\hline Youngstown & 100.4 & 98.0 & 102.5 & 98.9 & 99.2 \\
\hline
\end{tabular}


Table C.2 Geographic Adjustment Factors Used to Convert U.S. Average Cost Estimates to Their Local Equivalent Values for 156 Cities, by Type of Construction Activity (continued)

\section{Construction Activity}

\begin{tabular}{|c|c|c|c|c|c|}
\hline State/City & Painting & Masonry & $\begin{array}{l}\text { Moisture } \\
\text { Protection }\end{array}$ & Metals & $\begin{array}{l}\text { Weighte } \\
\text { Average }\end{array}$ \\
\hline \multicolumn{6}{|l|}{ Ok1 ahoma } \\
\hline Oklahoma City & 90.8 & 87.3 & 91.6 & 92.4 & 93.7 \\
\hline Tulsa & 84.8 & 90.4 & 93.7 & 100.5 & 93.7 \\
\hline \multicolumn{6}{|l|}{ Oregon } \\
\hline Eugene & 112.6 & 111.0 & 94.0 & 108.2 & 108.6 \\
\hline Portland & 105.2 & 113.5 & 92.9 & 108.3 & 108.5 \\
\hline \multicolumn{6}{|l|}{ Pennsylvania } \\
\hline A1lentown & 93.6 & 89.3 & 94.9 & 105.4 & 96.6 \\
\hline Erie & 90.8 & 98.7 & 96.6 & 98.3 & 97.0 \\
\hline Harrisburg & 91.0 & 81.8 & 84.8 & 98.6 & 92.8 \\
\hline Philadelphia & 97.5 & 91.5 & 103.0 & 102.8 & 98.2 \\
\hline Pittsburgh & 102.1 & 104.1 & 98.7 & 99.7 & 99.5 \\
\hline Reading & 91.0 & 89.7 & 88.7 & 97.9 & 94.2 \\
\hline Scranton & 91.7 & 93.4 & 95.6 & 99.0 & 96.5 \\
\hline \multicolumn{6}{|l|}{ Rhode Island } \\
\hline Providence & 97.8 & 96.1 & 102.7 & 105.6 & 97.7 \\
\hline \multicolumn{6}{|l|}{ South Carolina } \\
\hline Charleston & 78.0 & 73.3 & 83.4 & 92.0 & 83.9 \\
\hline Columbia & 80.1 & 72.0 & 87.8 & 96.5 & 83.5 \\
\hline \multicolumn{6}{|l|}{ South Dakota } \\
\hline Sioux Falls & 88.1 & 86.0 & 90.6 & 94.8 & 89.9 \\
\hline \multicolumn{6}{|l|}{ Tennessee } \\
\hline Chattanooga & 87.8 & 79.9 & 96.0 & 87.3 & 87.9 \\
\hline Knoxville & 79.9 & 72.6 & 81.5 & 94.2 & 85.7 \\
\hline Memphis & 90.4 & 91.8 & 100.5 & 92.5 & 92.7 \\
\hline Nashville & 69.3 & 76.1 & 92.1 & 88.1 & 84.5 \\
\hline \multicolumn{6}{|l|}{ Texas } \\
\hline Amarillo & 91.7 & 85.4 & 88.7 & 92.6 & 90.7 \\
\hline Austin & 82.4 & 89.6 & 91.4 & 90.3 & 90.2 \\
\hline Beaumont & 93.6 & 107.0 & 96.1 & 97.7 & 98.3 \\
\hline Corpus Christi & 81.9 & 79.9 & 87.3 & 92.3 & 87.2 \\
\hline Dallas & 95.7 & 97.4 & 96.6 & 97.3 & 96.1 \\
\hline E1 Paso & 76.0 & 75.8 & 88.7 & 95.3 & 85.8 \\
\hline Fort Worth & 92.0 & 92.9 & 91.8 & 99.8 & 96.1 \\
\hline Houston & 97.7 & 98.5 & 100.8 & 94.2 & 99.7 \\
\hline Lubbock & 85.6 & 85.5 & 88.5 & 87.0 & 89.4 \\
\hline San Antonio & 73.7 & 82.1 & 83.3 & 92.1 & 90.3 \\
\hline
\end{tabular}


Table C.2 Geographic Adjustment Factors Used to Convert U.S. Average Cost Estimates to Their Local Equivalent Values for 156 Cities, by Type of Construction Activity (continued)

Construction Activity

\begin{tabular}{|c|c|c|c|c|c|}
\hline State/City & Painting & Ma sonry & $\begin{array}{l}\text { Moisture } \\
\text { Protection }\end{array}$ & Metals & $\begin{array}{l}\text { Weighted } \\
\text { Average }\end{array}$ \\
\hline \multicolumn{6}{|l|}{ Utah } \\
\hline Salt Lake City & 86.3 & 93.0 & 90.7 & 103.8 & 96.9 \\
\hline \multicolumn{6}{|l|}{ Vermont } \\
\hline Burlington & 85.9 & 74.9 & 83.6 & 97.4 & 89.3 \\
\hline \multicolumn{6}{|l|}{ Virginia } \\
\hline Newport News & 75.7 & 76.9 & 80.6 & 83.5 & 85.2 \\
\hline Norfolk & 79.5 & 76.2 & 81.5 & 83.8 & 85.7 \\
\hline Richmond & 79.6 & 79.3 & 83.4 & 91.1 & 88.4 \\
\hline Roanoke & 75.9 & 70.3 & 80.7 & 90.4 & 85.0 \\
\hline \multicolumn{6}{|l|}{ Washingt on } \\
\hline Seattle & 106.4 & 114.9 & 108.4 & 106.5 & 106.5 \\
\hline Spokane & 108.9 & 108.0 & 100.4 & 104.2 & 105.1 \\
\hline Tacoma & 115.7 & 114.3 & 112.1 & 101.7 & 107.9 \\
\hline \multicolumn{6}{|l|}{ West Virginia } \\
\hline Charleston & 97.8 & 94.6 & 90.5 & 95.2 & 98.2 \\
\hline Huntington & 99.5 & 95.5 & 90.9 & 100.2 & 98.4 \\
\hline \multicolumn{6}{|l|}{ Wisconsin } \\
\hline Madison & 94.3 & 90.4 & 88.3 & 95.8 & 93.8 \\
\hline Milwaukee & 97.4 & 99.1 & 95.3 & 96.2 & 96.7 \\
\hline \multicolumn{6}{|l|}{ Wyoming } \\
\hline Cheyenne & 105.2 & 103.0 & 92.0 & 91.1 & 99.4 \\
\hline
\end{tabular}

Source: Means, Building Construction Cost Data 1984, pp. 323-331. 


\section{APPENDIX D: OTHER ADJUSTMENTS}

This appendix provides methods of adjusting the cost estimates given in appendix $B$ to take into account the (1) base period, (2) labor type (union or non-union), (3) project type (new or repalr and replacement), and (4) building project size. Each adjustment is discussed in turn and then an example is given for performing multiple adjustments to a cost estimate.

\section{D.1. Base Period}

Al1 the cost estimates presented in appendix B have a base year of 1984 , although the base period (i.e., month) within 1984 varies among the sources. Since more cost estimates are taken from the Means manuals, the following method is provided for converting the Berger and Dodge estimates to the same base period as Means (January 1984) for purposes of data consistency. To convert a cost estinate from Berger or Dodge to a corresponding January 1984 estimate, multiply it by the base-period conversion factor for that manual:

$\begin{array}{ll}\text { DODGE SYSTEMS } & 0.998 \\ \text { DODGE PRICING } & 0.993 \\ \text { BERGER } & 0.993\end{array}$

These factors were derived from a construction cost index focusing specifically on building construction: Dodge-McGraw Hill's Building Construction Cost Index, published in the Englneering News-Record and in two Department of Commerce publications, Construction Review and the Survey of Current Business. This monthly price index can be used to compute the percent change in building construction costs between any two time periods; it was used here to calculate the change from February to January 1984 (for the DODGE SYSTEMS manual) and the change from July to January 1984 (for the DODGE PRICING and BERGER manuals).

For example, appendix B (table B.15) reports a cost estimate from BERGER for copper roofing of $\$ 7.00$ per square foot. This flgure is based on costs in July 1984. The equivalent estimate with a base period of January 1984 is $\$ 6.95$ per square foot $(=7.00 \cdot 0.993)$.

\section{D.2 Labor Type and Project Type}

The labor type (union or non-union) employed for an MR\&R activity needs to be taken into account because union labor wage rates are significantly higher than non-union rates. Table D.I gives the cost of an MR\&R activity using non-union labor as a percent of the cost of the same activity using union labor. These figures we re calculated using union and non-union pay scales reported by trade in MEANS REP \& REM and MEANS RES/LT COM, respectively. By applying these percentage amounts to the union labor based cost estimates of Appendix B (all but those from MEANS RES/LT COM), one will obtain equivalent non-union labor based cost estimates.

Repalr and replacement construction generally involves higher overhead and profit rates than new construction. Table D.2 gives percentage anounts to be added to the new construction costs of Appendix B (all but those froin MEANS REP \& REM) to account for higher replacement construction overhead and profit. 
Table D.1 MR\&R Activity Cost Using Non-Union Labor, as a Percent of MR\&R Activity Cost Using Union Labor

$\begin{array}{lll}\text { Building } & \text { Building } & \text { Percent } \\ \text { Component } & \text { Material } & \end{array}$

Wa11s

Paint

71.2

Galvanized Steel

88.7

Limestone

76.4

Marble

71.6

Masonry Mortar

71.3

Roof $s$

Galvanized Steel

88.7

Copper

88.2

Gutters

Galvanized Steel

88.2

Copper

88.2

Downspouts

Galvanized Steel

88.2

Copper

88.2

Fences

Galvanized Steel

87.4

Sources: Table 2.2 of this report; Means, Bullding Construction Cost Data 1984, pp. vili-xxil; MEANS REP \& REM, inside back cover; and MEANS RES/LT COM, inside back cover. 
Table D.2 Percent to Add to MR\&R Activity Cost with New Construction Overhead and Profit to Obtain Equivalent Cost with Replacement Construction Overhead and Profit

\begin{tabular}{llc}
$\begin{array}{l}\text { Bullding } \\
\text { Component }\end{array}$ & $\begin{array}{l}\text { Bullding } \\
\text { Material }\end{array}$ & $\begin{array}{c}\text { Percent } \\
\text { to Add }\end{array}$ \\
\hline Walls & Paint & 5.5 \\
& $\begin{array}{l}\text { Galvanized Steel } \\
\text { Limestone } \\
\text { Marble }\end{array}$ & 1.5 \\
& Masonry Mortar & 4.2 \\
Roofs & Galvanized Steel & 5.7 \\
& Copper & 1.5 \\
Gutters & Galvanized Steel & 1.1 \\
& Copper & 1.1 \\
Downspouts & Galvanized Steel & 1.1 \\
& Copper & 1.1 \\
Fences & Galvanized Steel & 1.1 \\
\hline
\end{tabular}

Sources: Table 2.2 of this report; Means, Building Construction Cost Data 1984, pp. viil-xxii and 334; and MEANS REP \& REM, inside back cover. 
If a cost estimate is to be converted from both a union to a non-union labor base and from new construction overhead and profit to replacement construction overhead and profit, the percentage amounts in table D. 3 must be applied. Table D.3 gives the cost of an MR\&R activity using non-union labor with replacement construction overhead and profit as a percent of the cost of the same activity using union labor with new construction overhead and profit. DO NOT use tables D.1 and D.2 together to perform this conversion.

For replacement construction, special measures must sometimes be taken that add to the MR\&R activity cost. MEANS REP \& REM has developed a system for taking these special job requirements into account. Table D.4 gives percentage amounts, based on figures reported in MEANS REP \& REM, to be added to MR\&R activity cost estimates if the activities require that any of the special measures listed be taken. The figures in table D.4 apply only to replacement MR\&R activity cost estimates; new construction costs must be adjusted for replacement construction overhead and profit BEFORE these replacement construction special job requirements are accounted for. Note that if more than one special measure is necessary, one should apply the percentage amount for one of the measures to the replacement MR\&R activity cost, and then to the result apply the percentage amount for a second measure ${ }^{1}$, and so forth until all special measures are accounted for. The special job requirements included in the table are defined in MEANS REP \& REM as follows: ${ }^{2}$

1. Dust and noise protection of adjoining non-construction areas can alter usual construction methods.

2. Equipment usage curtailment resulting from physical limitations of the project may force workmen to use slow hand-operated equipment instead of power tools.

3. The confines of an enclosed bullding have a costly influence on movement and material handling.

4. On some repair or remodeling projects completed work must be secured or otherwise protected from possible damage during construction. In certain areas completed work must be guarded to prevent theft and vandalism.

5. Work may have to be done on other than nomal shifts and may have to be done around an existing production facility in operation during the repair and remodeling project.

6. Requirements for shoring and bracing to hold up the bullding while structural changes are being made will affect costs.

${ }^{1}$ Telephone conversation with Melville J. Mossman, MEANS REP \& REM, $9 / 17 / 85$.

${ }^{2}$ See pp. 6-7 
Table D.3 MR\&R Act1vity Cost Using Non-Union Labor w1th Replacement Construction Overhead and Prof1t, as a Percent of MR\&R Act1v1ty Cost Using Union Labor with New Construction Overhead and Proflt

Bullding

Component
Bullding

Material
Percent

$\begin{array}{llr}\text { Walls } & \text { Paint } & 74.7 \\ & \text { Galvanized Steel } & 89.7 \\ & \text { Limestone } & 79.1 \\ & \text { Marble } & 75.0 \\ & \text { Masonry Mortar } & 74.7 \\ \text { Roofs } & \text { Galvanized Steel } & 89.7 \\ & \text { Copper } & 88.8 \\ \text { Gutters } & \text { Galvanized Steel } & 88.8 \\ & \text { Copper } & 88.8 \\ \text { Downspouts } & \text { Galvanized Steel } & 88.8 \\ & \text { Copper } & 88.8 \\ \text { Fences } & \text { Galvanized Steel } & 88.8\end{array}$

Sources: Table 2.2 of this report; Means, Building Construction Cost Data 1984 , pp. vili-xil and 334; MEANS REP \& REM, Inside back cover; and MEANS RES/LT COM, inside back cover. 
If a cost estimate is to be converted from both a union to a non-union labor base and from new construction overhead and profit to replacement construction overhead and profit, the percentage amounts in table D. 3 must be applied. Table D.3 gives the cost of an MR\&R activity using non-union labor with replacement construction overhead and profit as a percent of the cost of the same activity using union labor with new construction overhead and profit. DO NOT use tables D.1 and D.2 together to perform this conversion.

For replacement construction, special measures must sometimes be taken that add to the MR\&R activity cost. MEANS REP \& REM has developed a system for taking these special job requirements into account. Table D.4 gives percentage amounts, based on figures reported in MEANS REP \& REM, to be added to MR\&R activity cost estimates if the activities require that any of the special measures 1isted be taken. The figures in table D.4 apply only to replacement $M R \& R$ activity cost estimates; new construction costs must be adjusted for replacement construction overhead and profit BEFORE these replacement construction special job requirements are accounted for. Note that if more than one speclal measure is necessary, one should apply the percentage amount for one of the measures to the replacement MR\&R activity cost, and then to the result apply the percentage amount for a second measurel, and so forth until all special measures are accounted for. The special job requirements included in the table are defined in MEANS REP \& REM as follows: ${ }^{2}$

1. Dust and noise protection of adjoining non-construction areas can alter usual construction methods.

2. Equipment usage curtallment resulting from physical limitations of the project may force workmen to use slow hand-operated equipment instead of power tools.

3. The confines of an enclosed bullding have a costly influence on movement and material handling.

4. On some repair or remodeling projects completed work must be secured or otherwise protected from possible damage during construction. In certain areas completed work must be guarded to prevent theft and vandalism.

5. Work may have to be done on other than normal shifts and may have to be done around an existing production facility in operation during the repair and remodeling project.

6. Requirements for shoring and bracing to hold up the bullding while structural changes are being made will affect costs. $9 / 17 / 85$.

${ }^{1}$ Telephone conversation with Melville J. Mossman, MEANS REP \& REM, ${ }^{2}$ See pp. 6-7 
Table D.3 MR\&R Activity Cost Using Non-Union Labor with Replacement Construction Overhead and Profit, as a Percent of MR\&R Activity Cost Using Union Labor with New Construction Overhead and Profit

$\begin{array}{lll}\text { Building } & \text { Building } & \text { Percent } \\ \text { Component } & \text { Material } & \end{array}$

\begin{tabular}{lll}
\hline Walls & Paint & 74.7 \\
& Galvanized Steel & 89.7 \\
& Limestone & 79.1 \\
& Marble & 75.0 \\
& Masonry Mortar & 74.7 \\
Roofs & Galvanized Stee1 & 89.7 \\
& Copper & 88.8 \\
Gutters & Galvanized Steel & 88.8 \\
& Copper & 88.8 \\
Downspouts & Galvanized Steel & 88.8 \\
& Copper & 88.8 \\
Fences & Galvanized Steel & 88.8 \\
\hline
\end{tabular}

Sources: Table 2.2 of this report; Means, Building Construction Cost Data 1984, PP. vili-xii and 334; MEANS REP \& REM, inside back cover; and MEANS RES/LT COM, inside back cover. 
Table D.4 Percent to Add to Replacement MR\&R Activity Cost to Account for Special Job Requirements, by Building Component and Material and by Job Requirement [Minimum \% - Maximum \%]

\begin{tabular}{|c|c|c|c|c|c|c|}
\hline \multirow[b]{2}{*}{$\begin{array}{l}\text { Bullding } \\
\text { Component \& } \\
\text { Material }\end{array}$} & \multicolumn{5}{|c|}{ Special Job Requi rement } & \multirow[b]{2}{*}{$\begin{array}{l}\text { Temporary } \\
\text { Shoring } \& \\
\text { Bracing }\end{array}$} \\
\hline & $\begin{array}{l}\text { Dust } \\
\text { Pro- } \\
\text { tection }\end{array}$ & $\begin{array}{l}\text { Equipment } \\
\text { Usage } \\
\text { Curtall- } \\
\text { ment }\end{array}$ & $\begin{array}{l}\text { Material } \\
\text { Handling \& } \\
\text { Storage } \\
\text { Limitation }\end{array}$ & $\begin{array}{l}\text { Protection } \\
\text { of } \\
\text { Existing } \\
\text { Work }\end{array}$ & $\begin{array}{l}\text { Shift } \\
\text { Work } \\
\text { Require- } \\
\text { ments }\end{array}$ & \\
\hline WALLS & & & & & & \\
\hline $\begin{array}{l}\text { Paint } \\
\text { Galvanized Steel } \\
\text { Limestone } \\
\text { Marble } \\
\text { Masonry Mortar }\end{array}$ & $\begin{array}{l}1 \cdot 8-9 \cdot 5 \\
1 \cdot 3-6 \cdot 1 \\
1 \cdot 5-8 \cdot 1 \\
1 \cdot 8-9 \cdot 4 \\
1 \cdot 8-9 \cdot 4\end{array}$ & $\begin{array}{l}1.0-8.5 \\
1.0-5.1 \\
0.9-7.2 \\
1.0-8.4 \\
1.0-8.4\end{array}$ & $\begin{array}{l}1.0-6.8 \\
1.0-6.3 \\
0.9-5.9 \\
1.0-6.8 \\
1.0-6.8\end{array}$ & $\begin{array}{l}2 \cdot 0-6 \cdot 6 \\
2 \cdot 0-5 \cdot 6 \\
1 \cdot 8-5 \cdot 7 \\
2 \cdot 0-6 \cdot 5 \\
2 \cdot 0-6 \cdot 5\end{array}$ & $\begin{array}{l}3 \cdot 9-23 \cdot 4 \\
1.5-9.2 \\
3 \cdot 3-19.6 \\
3.9-23 \cdot 2 \\
3.9-23 \cdot 2\end{array}$ & $\begin{array}{l}4.3-10.5 \\
2.9-7.1 \\
3.7-9.0 \\
4.3-10.4 \\
4.3-10.4\end{array}$ \\
\hline $\begin{array}{l}\text { ROOFS } \\
\text { Galvanized Steel } \\
\text { Copper }\end{array}$ & $\begin{array}{l}1.3-6.1 \\
1.4-6.6\end{array}$ & $\begin{array}{l}1.0-5.1 \\
1.0-5.2\end{array}$ & $\begin{array}{l}1 \cdot 0-6 \cdot 3 \\
1 \cdot 0-6 \cdot 3\end{array}$ & $\begin{array}{l}2.0-5 \cdot 6 \\
2.0-5 \cdot 6\end{array}$ & $\begin{array}{l}1.5-9.2 \\
1.6-9.4\end{array}$ & $\begin{array}{l}2.9-7.1 \\
2.9-7.2\end{array}$ \\
\hline $\begin{array}{l}\text { GUTTERS } \\
\text { Galvanized Steel } \\
\text { Copper }\end{array}$ & $\begin{array}{l}1.4-6 \cdot 6 \\
1.4-6.6\end{array}$ & $\begin{array}{l}1 \cdot 0-5 \cdot 2 \\
1.0-5 \cdot 2\end{array}$ & $\begin{array}{l}1 \cdot 0-6 \cdot 3 \\
1 \cdot 0-6 \cdot 3\end{array}$ & $\begin{array}{l}2.0-5.6 \\
2.0-5.6\end{array}$ & $\begin{array}{l}1.6-9.4 \\
1.6-9.4\end{array}$ & $\begin{array}{l}2.9-7.2 \\
2.9-7.2\end{array}$ \\
\hline $\begin{array}{l}\text { DOWNSPOUTS } \\
\text { Galvanized Steel } \\
\text { Copper }\end{array}$ & $\begin{array}{l}1.4-6.6 \\
1.4-6.6\end{array}$ & $\begin{array}{l}1.0-5 \cdot 2 \\
1.0-5 \cdot 2\end{array}$ & $\begin{array}{l}1 \cdot 0-6 \cdot 3 \\
1 \cdot 0-6 \cdot 3\end{array}$ & $\begin{array}{l}2.0-5.6 \\
2.0-5.6\end{array}$ & $\begin{array}{l}1.6-9.4 \\
1.6-9.4\end{array}$ & $\begin{array}{l}2.9-7.2 \\
2.9-7.2\end{array}$ \\
\hline $\begin{array}{l}\text { FENCES } \\
\text { Galvanized Steel }\end{array}$ & $1.3-6 \cdot 4$ & $1.0-5 \cdot 4$ & $1.0-6 \cdot 3$ & $2 \cdot 0-5 \cdot 7$ & $1.7-10.4$ & $3.0-7.4$ \\
\hline
\end{tabular}

Sources: Table 2.2 of this report and MEANS REP \& REM, PP. xv, xvi, and 6 . 


\section{D.3 Economies of Scale}

The following equation can be used to adjust cost estimates for building project sizes that differ from the project size assumed by the published data source in which the cost estimate was found:

$$
y=1.03-.03 x
$$

where $y=$ the adjustment factor, and

$\mathrm{x}=$ the ratio of desired project size to data source project size.1

For example, suppose one wants to apply a cost estimate for replacing galvanized steel siding from a data source reporting costs from $\$ 1,000,000$ building projects to a building project costing $\$ 500,000$. The galvanized steel siding cost estimate reported in the data source is $\$ 1.50$ per square foot. The ratio of desired to data source project sizes is 0.5 $(=\$ 500,000 / \$ 1,000,000)$. The adjustment factor is $1.015(=1.03-.03(.5))$. The resulting cost of replacing galvanized steel siding adjusted for a $\$ 500,000$ building project is $\$ 1.52$ per square foot $(=1.50,1.015)$.

\section{D.4 Performing More than One Adjustment}

If more than one cost data adjustment is necessary, they may be performed in any sequence, including the geographic adjustments given in appendix $C$. The following example illustrates how multiple adjustments can be applied to a single MR\&R activity cost estinate from appendix $B$.

Suppose a 1.5 inch thick marble wall is to be replaced. Assume that non-union labor is to be used, surrounding non-construction areas must be kept free of dust, and the work must be performed on early morning shifts. One of the cost estimates from MEANS REP \& REM for this MR\&R activity is $\$ 27.42$ per square foot. (See appendix B, table B.11, item 14.)

Since the cost estinate is from MEANS REP \& REM, an adjustment to non-union labor must be made. Special job requirements apply, so replacement rather than new construction cost estimates must be used. MEANS REP \& REM gives such replacement cost estimates, so that the adjustment given in table D.2 for replacement versus new construction overhead and profit need not be made in this case. Thus, table D.I can be used for the labor type conversion. There one finds that replacing marble walls with non-union labor will cost 71.6 percent of the $\$ 27.42$ cost for replacing marble walls with union labor. So the estinate now becomes $\$ 19.63$ per square foot $(=27.42 \cdot 0.716)$.

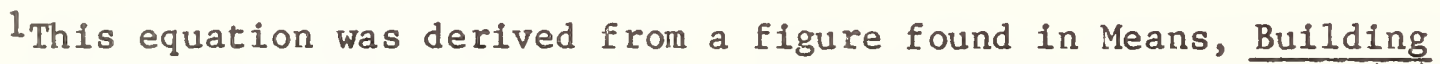
Construction Cost Data 1984, p. 402. In a telephone conversation 7/8/85, Melville J. Mossman of Means indicated that the equation could be used to extrapolate beyond the range of values given in the figure. He also confirmed that the equation could be applied to MR\&R activities in addition to entire building projects. 
Now the two special job requirements can be taken into account. The amount to be applied to a replacement MR\&R activity cost estimate for marble walls to account for both dust protection and shift work requirements can be derived from table D.4 as follows: the minimum is 1.058 ( $=1.018 .1 .039)$; and the maximum is $1.348(=1.094 \cdot 1.232)$. Consequently, the cost estimate for replacing marble walls adjusted for both labor type and special job

requirements is, at a minimum, $\$ 20.77$ per square foot $(=19.63 \cdot 1.058)$, and at a maximum, $\$ 26.46$ per square foot $(=19.63 \cdot 1.348)$. 


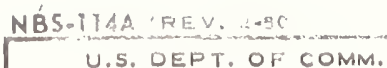

BIBLIOGRAPHIC DATA

SHEET (See instructions)

\section{PUBLICATION OR REPORT NO. \\ NBSIR- $85 / 3253$}

2. Performing Organ. Report No. 3. Publication Date

October 1985

4. TITLE AND SUBTITLE

A Life-Cycle Cost Data Base for Assessing Acid Deposition Damage to Common Building Materials

\section{5. $\operatorname{AUTHOR}(\mathrm{S})$}

Weber, Stephen F.; Lippiatt, Barbara C.; Wiener, Matthew

6. PERFORMING ORGANIZATION (If joint or other than NBS, see instructions)

7. Contract/Grant No.

NATIONAL BUREAU OF STANDARDS

DEPARTMENT OF COMMERCE

WASHINGTON, D.C. 20234

8. Type of Report \& Period Covered

9. SPONSORING ORGANIZATION NAME AND COMPLETE ADDRESS (Street, City, State, ZIP)

Final

U.S. Environmental Protection Agency

Washington, DC 20460

As part of the National Acid Precipitation Assessment Program

Materials Effects Task Group (Group G)

10. SUPPLEMENTARY NOTES

Document describes a computer program; SF-185, FIPS Software Summary, is attached.

11. ABSTRACT (A 200-word or less factual summary of most significant information. If document includes a significant bibliography or literature survey, mention it here)

This report presents and documents cost data for the most economically significant building materials suspected of being damaged by acid deposition. The data are presented in the form of cost estimates for relevant maintenance, repair, and replacement (MR\&R) activities, and are organized both by building component and by building material. The building components covered in this report include walls, roofs, fences, rain gutters, and downspouts. The materials covered include paint, limestone, marble, galvanized steel, copper, and masonry mortar. The documentation describes the data sources and presents detailed technical specifications for each of the 360 cost estimates contained in the data base. Summary statistics are presented for groups of MR\&R activities, and the techniques of analysis of variance and regression analysis are used to address the problem of variation in the cost estimates within the same activity group. The report also explains and illustrates how the cost data can be used to estimate the economic cost of acid deposition damage to common building components and materials.

12. KEY WORDS (Six to twelve entries; alphabetical order: capitalize only proper names; and separate key words by semicolons) acid rain; buildings; cost data; damage; data base; economics; environment; 1ifecycle cost; maintenance; materials; repair; replacement

13. AVAILABILITY

[x] Unlimited

$\square$ For Official Distribution. Do Not Release to NTIS

[] Order From Superintendent of Documents, U.S. Government Prlnting Office, Washington, D.C. 20402.

Exx Order From National Technical Information Service (NTIS), Springfield, VA. 2216I
14. NO. OF PRINTED PAGES

84

15. Price

$\$ 11.95$ 

